\title{
Balance Sheets, Exchange Rates, and International Monetary Spillovers*
}

\author{
Ozge Akinci ${ }^{\dagger}$ \\ Federal Reserve Bank of New York \\ Albert Queralto ${ }^{\ddagger}$ \\ Federal Reserve Board
}

September 28, 2018

\begin{abstract}
We use a two-country New Keynesian model with balance sheet constraints to investigate the magnitude of international spillovers of U.S. monetary policy. Home borrowers obtain funds from domestic households in domestic currency, as well as from residents of the foreign economy (the U.S.) in dollars. In our economy, foreign lenders differ from domestic lenders in their ability to recover resources from borrowers' assets, leading to more severe financial frictions for foreign debt than for domestic deposits. As a consequence, a deterioration in borrowers' balance sheets induces a rise in the home currency's premium and an exchange rate depreciation. We use the model to investigate how spillovers are affected by the degree of currency mismatches in balance sheets, and whether the latter make it desirable for policy to target the exchange rate. We find that the magnitude of spillovers is significantly enhanced by the degree of currency mismatches. Our findings also suggest that using monetary policy to stabilize the exchange rate is not necessarily more desirable with greater balance sheet mismatches and may actually exacerbate short-run exchange rate volatility.
\end{abstract}

Keywords: Financial Frictions; U.S. Monetary Policy Spillovers; Currency Premium; Uncovered Interest Rate Parity Condition.

JEL classification: E32; E44; F41.

\footnotetext{
${ }^{*}$ The authors thank Chris Erceg for many fruitful discussions that inspired much of this work, as well as Giancarlo Corsetti (discussant), Jordi Gali, Sebnem Kalemli-Ozcan, Paolo Pesenti, and Jenny Tang (discussant) for very useful comments. They also thank participants for their comments at the NBER conference Capital Flows, Currency Wars and Monetary Policy, the Federal Reserve Board, the Federal Reserve Bank of New York, and the SCIEA meeting at the Federal Reserve Bank of San Francisco. The views expressed in this paper are those of the authors and do not necessarily reflect the position of the Federal Reserve Bank of New York, the Board of Governors of the Federal Reserve, or the Federal Reserve System.

${ }^{\dagger}$ Federal Reserve Bank of New York, 33 Liberty Street, New York, NY 10045, U.S.A. Email: ozge.akinci@ny.frb.org.

${ }^{\ddagger}$ Federal Reserve Board, 20th St\&Cons. Ave,NW, Washington, DC, 20551, USA. Email: albert.queralto@frb.gov.
} 


\section{Introduction}

With U.S. monetary policy normalization well underway, an important question facing monetary policymakers across the globe is to what extent rising U.S. interest rates can have adverse spillovers to their own economies, and what are the trade-offs they face in this environment. A common view, particularly among emerging market economies, recommends gearing policy toward preventing capital outflows and mitigating currency depreciation. A frequent argument underlying this view is the presence of currency mismatches in borrowers' balance sheets, which render the latter undesirably vulnerable to movements in the nominal exchange rate. ${ }^{1}$

Our goal in this paper is to investigate how the degree of currency mismatch in the balance sheets of the domestic private sector may affect the degree of spillovers from U.S. monetary policy, and to lay out its consequences for the trade-offs faced by domestic monetary policymakers. In particular, we investigate whether currency mismatch provides grounds for an interest rate policy that attempts to stabilize the nominal exchange rate, as argued by the common view described above.

To that end, we develop a two-country New Keynesian model, consisting of a "home" economy (e.g. an emerging market economy) and the U.S., and augment it with financial frictions in the banking sector of the home economy. We then allow for dollar-denominated liabilities in home banks' balance sheets, by assuming that domestic banks can borrow from U.S. households (in dollars) as well as from domestic households (in domestic currency). In each case, banks' borrowing is subject to enforcement frictions, modeled as in Gertler and Kiyotaki (2010). Because banks' assets consist of home productive capital (denominated in home currency), the presence of dollar liabilities creates a currency mismatch whereby a depreciation of the home currency worsens domestic balance sheets.

The key novel mechanism in our setting involves self-reinforcing feedback between the exchange rate and domestic financial conditions. This mechanism arises because the state of domestic balance sheets exerts a powerful influence on the value of the domestic currency, owing to the credit market friction. Thus, our model features a financial channel of spillovers from U.S. monetary contractions, over and above the more-familiar trade spillovers featuring expenditure-switching and expenditure-reducing channels.

We begin by presenting a simple open economy model designed to isolate the role of

\footnotetext{
${ }^{1}$ Calvo and Reinhart (2002) and Hausmann, Panizza and Stein (2001), for example, appeal to currency mismatches in balance sheets, and the consequent sensitivity of the latter to exchange rate variations, as an explanation for the observed "fear of floating" among emerging economies.
} 
balance sheet constraints on exchange rate determination. We show how a domestic balance sheet deterioration induces a rise in the currency premium, an exchange rate depreciation, and a capital outflow. Key to this mechanism is the assumption that enforcement frictions affect foreign borrowing more severely than domestic borrowing. ${ }^{2}$ The resulting imperfect arbitrage between domestic and foreign loans leads to a failure of uncovered interest parity (UIP henceforth), the magnitude of which is linked to the domestic credit spread and, in general equilibrium, to the state of domestic balance sheets.

We embed this mechanism within a medium-scale two-country New Keynesian model with empirically realistic features. Unlike the simple model described above (in which borrowers' net worth is governed by an exogenous equity endowment) here the state of borrowers' balance sheets evolves endogenously, and its sensitivity to the exchange rate increases as the extent of mismatch rises - accounting for the self-reinforcing feedback described earlier. We use the model to investigate the size of the spillovers from U.S. monetary tightening, and how it is affected by the degree of mismatches in home balance sheets. We also use the model to examine the consequences of using domestic monetary policy to try to stabilize the exchange rate in the face of U.S. monetary shocks.

The main findings that emerge from our analysis are as follows. First, the expenditureswitching and expenditure-reducing channels roughly cancel each other in our baseline calibration, so that the size of spillovers is mainly driven by the financial channel. In addition, the magnitude of the latter is significantly enhanced by the degree of currency mismatch in balance sheets. The reason is the downward pressure on the domestic currency (vis-à-vis the dollar) exerted by a U.S. policy rate hike. The depreciation of the home currency initiates larger losses in domestic balance sheets when the degree of currency mismatch is higher, setting off the adverse feedback loop between exchange rates and balance sheets. The presence of foreign-currency debt magnifies the depreciation, via greater feedback between exchange rate and borrowers' net worth. ${ }^{3}$

We next examine the spillovers from U.S. monetary policy under an alternative policy

\footnotetext{
${ }^{2}$ This assumption attempts to capture the realistic notion that it is harder for foreign creditors to monitor home-economy borrowers and enforce contracts with them than it is for domestic creditors.

${ }^{3}$ Our baseline model features producer currency pricing (PCP) in which an exchange rate depreciation is fully passed through to import prices, leading consumers to switch from foreign goods towards cheaper domestic goods (the expenditure-switching channel). Under the dominant currency pricing (DCP) paradigm recently emphasized by Gopinath (2016) and Boz et al. (2017), the degree of spillovers from a U.S. monetary tightening on domestic output is larger, as the benefits arising from greater foreign demand for home's products (due to a depreciated home currency) is very small. We explore the consequences of DCP within our framework in section 4.3.1.
} 
regime in which the domestic monetary authority systematically raises the policy rate as the nominal exchange rate depreciates. Our key finding is that the appeal of such a policy may actually diminish as the degree of currency mismatch rises, rather than increasing as suggested by the conventional view. In the case of a very high degree of currency mismatch, the alternative policy regime (the one that targets the nominal exchange rate) induces an enormous output drop following a U.S. tightening, and does not even succeed in containing the short-run exchange rate depreciation.

To illustrate the intuition behind this finding, we show that the degree of currency mismatch significantly affects the transmission of domestic monetary policy as well, particularly regarding the behavior of the real and nominal exchange rate. Because a domestic interest rate hike hurts balance sheets, it induces a rise in the currency premium, which partially counteracts the standard effect through the UIP leading to an exchange rate appreciation. This effect turns more powerful as the extent of currency mismatch rises, because balance sheets turn more sensitive to a currency depreciation - thus exacerbating the adverse feedback between the state of balance sheets and the exchange rate. When the currency mismatch is very high, a monetary tightening actually leads the currency to depreciate in the short run, due to a sharp rise in the currency premium. This result from our theoretical model is consistent with the empirical evidence documented by Hnatkovska et al. (2016), who find that emerging market economy currencies tend depreciate against the US dollar when domestic rates increase relative to the U.S. rates, in contrast to advanced-economy currencies. More generally, the result may help explain the difficulty in identifying empirically a robust relationship between domestic interest rates and exchange rates in emerging market economies, particularly in times of heightened financial stress (see, for example, Gould and $\operatorname{Kamin}(2001))$.

Compared to standard New Keynesian models like Gali and Monacelli (2005), in which a UIP condition always holds, our model features significant deviations from uncovered interest parity, which are related to the state of domestic balance sheets (and therefore linked to domestic credit spreads). In the empirical section of the paper, we provide a test this feature of the model. We do so by augmenting Fama regressions (Fama (1984)) with measures of domestic credit spreads, which proxy for the domestic external finance premium. Here we find significant support for the basic model prediction linking the currency premium with domestic credit spreads. Our model is also broadly consistent with the findings in Baskaya et al. (2018), who provide micro-level empirical evidence of a UIP failure over the 2003-2013 period in Turkey. Their empirical results - showing that foreign currency borrowing in a 
typical emerging market economy tends to be cheaper than local currency borrowing - are also consistent with a basic feature of our model, in which imperfect arbitrage (arising due to agency frictions) allows the existence of a wedge between the return on domestic borrowing and that on foreign loans (adjusted by the expected movement in the currency value).

Our paper is related to several strands in the literature. Our model builds on the New-Keynesian open economy macroeconomic frameworks developed by Gali and Monacelli (2005) and Erceg et al. (2007). The model is augmented to include financial frictions in the banking sector as in Gertler and Kiyotaki (2010) and Gertler and Karadi (2011), as well as a balance sheet channel of exchange rate changes as in Céspedes et al. (2004) (see also Gertler et al. (2007), Aghion et al. (2001), Aghion et al. (2004), Krugman (1999), and Braggion et al. (2009)). This feature of the model is consistent with the recent empirical evidence on the link between balance sheets and exchange rates. For example, KalemliOzcan et al. (2016) and Niepmann and Schmidt-Eisenlohr (2017), among others, document adverse effects of currency depreciations on real and financial variables in the presence of foreign-denominated debt. ${ }^{4}$

Our paper is also related to recent influential work by Aoki, Benigno and Kiyotaki (2016), Bocola and Lorenzoni (2017), Corsetti et al. (2018), Gabaix and Maggiori (2015), and Bruno and Shin (2015). The distinctive features of our work compared to these papers are that we focus on quantifying the spillovers from U.S. monetary tightening, that we use a two-country medium-scale New Keynesian model augmented with a set of features designed to enhance its quantitative realism, and that we emphasize the transmission arising through endogenous UIP deviations and their interaction with the degree of currency mismatch in balance sheets.

The paper is organized as follows. We begin by describing, in Section 2, a simple open economy model aimed at isolating the role of domestic balance sheets on deviations from UIP - the key novel element in our setting relative to Gali and Monacelli (2005) or Erceg et al. (2007). Section 3 describes the full model. Section 4 shows our quantitative experiments. Section 5 contains the empirical analysis. Section 6 concludes.

\section{Simple Model}

We begin with a very simple, stripped-down version of the model which allows us to isolate the role of the state of balance sheets in driving the currency premium and the exchange rate.

\footnotetext{
${ }^{4}$ Goldstein and Turner (2004) and Chui, Kuruc and Turner (2016) also document that currency mismatches are still pervasive in emerging market economies.
} 
The model consists of a foreign economy (the U.S.) and a domestic economy populated by households, firms, and bankers. There are two distinct nondurable consumption goods (one produced at home and the other produced abroad) as well a durable capital good. Home bankers borrow from domestic households and from U.S. households to fund the acquisition of physical capital. An agency friction potentially limits bankers' ability to borrow (from both domestic and foreign creditors). Aside from the agency friction, the model features no other real or nominal imperfections. We assume there are no financial frictions in the foreign economy.

\subsection{Banks}

We assume each banker $i$ lives for two periods, and operates on behalf of the representative household. ${ }^{5}$ At the beginning of the period, the banker receives an exogenous equity transfer $\xi_{i t}$ from the household. The banker then uses this equity endowment as well as borrowed funds from domestic households ( $D_{i t}$, in units of the domestic good) and foreign households $\left(D_{i t}^{*}\right.$, in units of the foreign good) to finance purchases of the capital good, denoted $S_{i t}$ :

$$
q_{t} S_{i t}=D_{i t}+\mathcal{Q}_{t} D_{i t}^{*}+\xi_{i t}
$$

where $q_{t}$ is price of capital and $\mathcal{Q}_{t}$ is the price of the foreign good (both in terms of the domestic good). We refer to $\mathcal{Q}_{t}$ as the real exchange rate. $S_{i t}$ denotes bank $i$ 's holdings of claims on domestic capital. We assume that there are no financing frictions between banks and non-financial firms (the ultimate users of physical capital), and therefore the payoff that bankers obtain from each claim is given by the capital dividend obtained by non-financial firms. Thus, the banker can be thought of as a holder of equity of domestic firms. For this reason, we think of banks more broadly as "bank-firms" capturing the entire corporate sector.

In $t+1$, the bank receives net payment

$$
\underbrace{\frac{r_{k t+1}+q_{t+1}}{q_{t}}}_{\equiv R_{K t+1}} q_{t} S_{i t}-R_{t+1} D_{i t}-R_{t+1}^{*} \mathcal{Q}_{t+1} D_{i t}^{*}
$$

which he or she transfers to the household and then exits. Here $r_{k t+1}$ is the dividend payout and $R_{t+1}, R_{t+1}^{*}$ are the (noncontingent) real interest rates on domestic and foreign funds,

\footnotetext{
${ }^{5}$ In the larger-scale model presented later, we allow for long-lived bankers.
} 
respectively.

The agency friction affecting banks' financing takes the form of a simple limited enforcement problem: after borrowing funds the banker may, rather than honoring its obligations, decide instead to default on its creditors and divert the amount

$$
\begin{aligned}
& \theta\left(D_{i t}+(1+\gamma) \mathcal{Q}_{t} D_{i t}^{*}+\xi_{i t}\right) \\
= & \theta\left(1+\gamma x_{i t}\right) q_{t} S_{i t}
\end{aligned}
$$

for personal gain, where $x_{i t} \equiv \frac{\mathcal{Q}_{t} D_{i t}^{*}}{q_{t} S_{i t}}, 0<\theta<1$, and $\gamma>0$.

The latter assumption, $\gamma>0$, captures the notion that the bank can more easily divert resources when they are financed by foreign loans, rather than by domestic loans. ${ }^{6}$ We believe this is a natural assumption: It captures the notion that it is harder for foreign creditors to monitor borrowers and enforce contracts than it is for domestic creditors. Upon default, creditors liquidate the bank and recover the remaining amount. For creditors to be willing to supply funds in the first place, the banker's choices need to satisfy an incentive constraint requiring the bank's continuation value to be higher than the value of defaulting and diverting funds.

Let

$$
\begin{aligned}
\mu_{t} & \equiv \beta \mathbb{E}_{t}\left(R_{K t+1}-R_{t+1}\right) \\
\varrho_{t} & \equiv \beta \mathbb{E}_{t}\left(R_{K t+1}-\frac{R_{t+1}^{*} \mathcal{Q}_{t+1}}{\mathcal{Q}_{t}}\right)
\end{aligned}
$$

The variable $\mu_{t}$ denotes expected excess returns with respect to the domestic rate $R_{t+1}$, while $\varrho_{t}$ is expected excess returns relative to the foreign borrowing rate. The variable $x_{i t}$ is the foreign funding ratio - the ratio of the bank's foreign liabilities (expressed in real domestic currency) to total assets. Each banker solves the following problem:

$$
\max _{S_{i t}, x_{i t}}\left[x_{i t} \varrho_{t}+\left(1-x_{i t}\right) \mu_{t}\right] q_{t} S_{i t}+\xi_{i t}
$$

\footnotetext{
${ }^{6}$ To see this, let $\xi_{i t} \rightarrow 0$ and consider a bank that finances its assets solely with loans from domestic residents $\left(D_{i t}^{*}=0\right)$. The bank's payoff from defaulting is $\theta q_{t} S_{i t}$. If, on the other hand, the bank finances its asset holdings only with foreign funds $\left(D_{i t}=0\right)$ its payoff from defaulting is $\theta(1+\gamma) q_{t} S_{i t}$. Thus $\gamma$ indexes the degree to which foreign funds are more easily divertible.
} 
subject to

$$
\left[x_{i t} \varrho_{t}+\left(1-x_{i t}\right) \mu_{t}\right] q_{t} S_{i t}+\xi_{i t} \geq \theta\left(1+\gamma x_{i t}\right) q_{t} S_{i t}
$$

The incentive constraint (IC) above requires that the banker's continuation value be higher than the value of defaulting.

Given a binding IC, the banker's first order conditions imply the optimal liability portfolio condition

$$
(1+\gamma) \mu_{t}=\varrho_{t}
$$

The intuition is straightforward. Consider an operation whereby the bank marginally increases its foreign borrowing, financed by a decrease of the amount of borrowing from the domestic market. The benefit of this operation is $\varrho_{t}$, the excess return on foreign borrowing. The cost is $(1+\gamma) \mu_{t}$, the excess return on domestic borrowing $\left(\mu_{t}\right)$ plus the loss due to a tighter IC, $\gamma \mu_{t}$ (recall that an extra unit of foreign borrowing tightens the constraint by $\gamma$ marginally). If the bank's portfolio is optimal in the first place, the benefit of the operation must equal its cost.

The wedge in the UIP condition (or the "currency premium") is then given by:

$$
\begin{aligned}
\mu_{t}^{*} & \equiv \beta \mathbb{E}_{t}\left(R_{t+1}-\frac{R_{t+1}^{*} \mathcal{Q}_{t+1}}{\mathcal{Q}_{t}}\right) \\
& =\varrho_{t}-\mu_{t} \\
& =\gamma \mu_{t}
\end{aligned}
$$

Thus the foreign exchange premium is proportional to the domestic excess return $\mu_{t}$, with the constant of proportionality given by the parameter $\gamma$.

Throughout we assume that the primitive parameters are such that the IC binds in a neighborhood of the steady state, so that

$$
\left(1+\gamma x_{i t}\right) q_{t} S_{i t}=\frac{\xi_{i t}}{\theta-\mu_{t}}
$$

for all $i$. 


\section{$2.2 \quad$ Households and export demand}

The representative consumer maximizes

$$
\mathbb{E}_{0} \sum_{t=0}^{\infty} \beta^{t} U\left(C_{D t}, M_{C t}\right)
$$

subject to

$$
C_{D t}+\mathcal{Q}_{t} M_{C t}+D_{t} \leq W_{t} \bar{L}+R_{t} D_{t-1}+\pi_{t}
$$

$C_{D t}$ is consumption of the domestic good (whose price is normalized to 1), $M_{C t}$ is imports of the foreign good, $D_{t}$ is bank deposits, and $\pi_{t}$ is net transfers from bankers. Assuming preferences take the form $U\left(C_{D}, M_{C}\right)=C_{D}+\chi_{m} \log \left(M_{C}\right)$, we get the following first-order conditions:

$$
\begin{aligned}
R & =\beta^{-1} \\
M_{C t} & =\chi_{m} \mathcal{Q}_{t}^{-1}
\end{aligned}
$$

Given symmetric preferences in the foreign country, export demand from the foreign country is analogous to import demand: $M_{C t}^{*}=\chi_{x} \mathcal{Q}_{t}$. We assume inelastic labor supply and linear utility in $C_{D}$ for simplicity, as these features are not essential (qualitatively) to the transmission from balance sheets to exchange rates. On the other hand, it is important to allow for a qualitatively realistic response of net exports to the real exchange rate, justifying the assumption of curvature in the preferences for imports and exports.

\subsection{Equilibrium conditions}

We assume the aggregate supply of physical capital is fixed at $\bar{K}$. Capital market clearing is then given by $\int S_{i t} d i=\bar{K}$. We assume banks' transfer is $\xi_{i t}=\xi_{t} q_{t} \bar{K}$, where $\xi_{t}$ follows an exogenous process with mean $\xi \in(0,1)$. Aggregating banks' incentive constraint (6) and assuming symmetry, we obtain

$$
1+\gamma x_{t}=\frac{1}{\theta-\mu_{t}} \xi_{t}
$$


Aggregating domestic budget constraints (where $R^{*}=\beta^{*-1}<R$ ), we obtain

$$
\begin{aligned}
R^{*} D_{t-1}^{*}-D_{t}^{*} & =N X_{t} \\
N X_{t} & =\chi_{x}-\chi_{m} \mathcal{Q}_{t}^{-1}
\end{aligned}
$$

where $N X_{t}$ is net exports expressed in terms of the foreign good $\left(N X_{t} \equiv \mathcal{Q}_{t}^{-1} M_{C t}^{*}-M_{C t}\right){ }^{7}$

We assume firms are perfectly competitive and operate a Cobb-Douglas technology $Y_{t}=$ $K_{t}^{\alpha} L_{t}^{1-\alpha}$. Given the aggregate supplies of labor and capital $\bar{K}$ and $\bar{L}$, the dividend payout is then $r_{k t}=r_{k}=\alpha(\bar{K} / \bar{L})^{\alpha-1} \forall t$.

The full set of equilibrium conditions characterizing the home economy consists of 5 equations determining $x_{t}, \mu_{t}, \mathcal{Q}_{t}, q_{t}$ and $D_{t}^{*}: 8$

$$
\begin{aligned}
\mu_{t} & =\theta-\frac{\xi_{t}}{1+\gamma x_{t}} \\
x_{t} & =\frac{\mathcal{Q}_{t} D_{t}^{*}}{q_{t} \bar{K}} \\
q_{t} & =\beta \frac{\mathbb{E}_{t}\left(\bar{r}_{K}+q_{t+1}\right)}{1+\mu_{t}} \\
\mathcal{Q}_{t} & =\frac{\frac{\beta}{\beta^{*}} \mathbb{E}_{t}\left(\mathcal{Q}_{t+1}\right)}{1-\gamma \mu_{t}} \\
D_{t}^{*} & =\frac{\chi_{m}}{\mathcal{Q}_{t}}-\chi_{x}+R^{*} D_{t-1}^{*}
\end{aligned}
$$

Equation 11 is the incentive constraint (6), determining the domestic excess return $\mu_{t}$ as a function of the equity transfer $\xi_{t}$ and the foreign funding ratio $x_{t}$. Equation (12) is the definition of $x_{t}$. Equations (13) and (14) follow from (2) and (5), and determine prices $q_{t}, \mathcal{Q}_{t}$ as a function of $\mu_{t}$ and expectations of $q_{t+1}$ and $\mathcal{Q}_{t+1}$. The balance of payments equation (15) follows from (9) and (10).

We next consider a first-order approximation to the system (11)-(15) around the nonstochastic steady state. Further, we also assume that $\beta$ is arbitrarily close to $\beta^{*}$, let $\chi_{m}=\chi_{x}$, and choose an appropriate normalization of $\bar{K}$ such that the elasticity of $N X_{t}$ to $\mathcal{Q}_{t}$ equals unity. Under these assumptions, letting $\widehat{y}_{t} \equiv \log \left(\frac{y_{t}}{y}\right)$ and $\widetilde{y}_{t} \equiv y_{t}-y$ for any variable $y_{t}$, the system (11)-(15) becomes $^{9}$

\footnotetext{
${ }^{7}$ See Appendix A for the derivation of equations (9) and (10).

${ }^{8}$ Appendix A contains the model's steady state and log-linearized equilibrium conditions.

${ }^{9}$ See Appendix A.3 for details.
} 


$$
\begin{aligned}
\widetilde{\mu}_{t} & =-\frac{\theta}{\xi} \widetilde{\xi}_{t}+\frac{\theta}{\xi}(\xi-\theta) \widehat{x}_{t} \\
\widehat{x}_{t} & =\widehat{\mathcal{Q}}_{t}+\widehat{D}_{t}^{*}-\widehat{q}_{t} \\
\widehat{\mathcal{Q}}_{t} & =\gamma \widetilde{\mu}_{t}+\mathbb{E}_{t}\left\{\widehat{\mathcal{Q}}_{t+1}\right\} \\
\widehat{q}_{t} & =-\widetilde{\mu}_{t}+\beta \mathbb{E}_{t}\left\{\widehat{q}_{t+1}\right\} \\
\widehat{D}_{t}^{*} & =-r^{*} \widehat{\mathcal{Q}}_{t}+\left(1+r^{*}\right) \widehat{D}_{t-1}^{*}
\end{aligned}
$$

where $r^{*} \equiv \frac{1}{\beta^{*}}-1$ is the net foreign interest rate.

The system above makes the mechanics of the model reasonably transparent. A drop in $\widetilde{\xi}_{t}$ works to push excess returns $\widetilde{\mu}_{t}$ up from (16), given $\widehat{x}_{t}$. From 19, $\widehat{q}_{t}$ is determined by (the negative of) current and future expected values of $\widetilde{\mu}_{t}$, so rises in the latter work to depress the asset price. Similarly, from (18) rising excess returns depreciate the home currency, with the strength of the effect governed by parameter $\gamma$. The intuition follows from condition (5), in turn a consequence of the optimal portfolio condition (4): rising excess returns must be matched by a rise in the UIP wedge $\mu_{t}^{*}$, which must take place via a depreciation along with expected appreciation of the home currency. Rising $\widehat{\mathcal{Q}}_{t}$ and falling $\widehat{q}_{t}$ both affect $\widehat{x}_{t}$ positively, with a drop in $\widehat{D}_{t}^{*}$ working in the opposite direction. The latter effect, however, will tend to be relatively small, as the elasticity of $D_{t}^{*}$ to $\mathcal{Q}_{t}$ is the net interest $r^{*}$.

\subsection{Effects of drop in net worth}

We next illustrate the mechanics just described by means of an impulse response to a negative innovation to $\xi_{t}$. We calibrate the discount factors, $\beta$ and $\beta^{*}$, to 0.9925 and 0.9975 respectively, following our calibration of the larger-scale model described in detail below. We set the divertable fraction of assets to 0.2 , the steady-state equity transfer to 25 percent of the value of capital, and assume that foreign credit is fifty percent more divertable than domestic credit $(\gamma=0.5)$. We emphasize, however, that the basic qualitative patterns hold regardless of the specific calibration (so long as the conditions on parameters described in Appendix A.2 are satisfied).

What are the consequences of a drop in aggregate net worth? Figure 1 shows the impulse responses to a negative innovation of two percentage points percent to $\xi_{t}$ (i.e. the transfer falls from 25 to 23 percent of the value of capital) which persists with autoregressive parameter 
Figure 1: Negative $\xi$ shock in the simple model
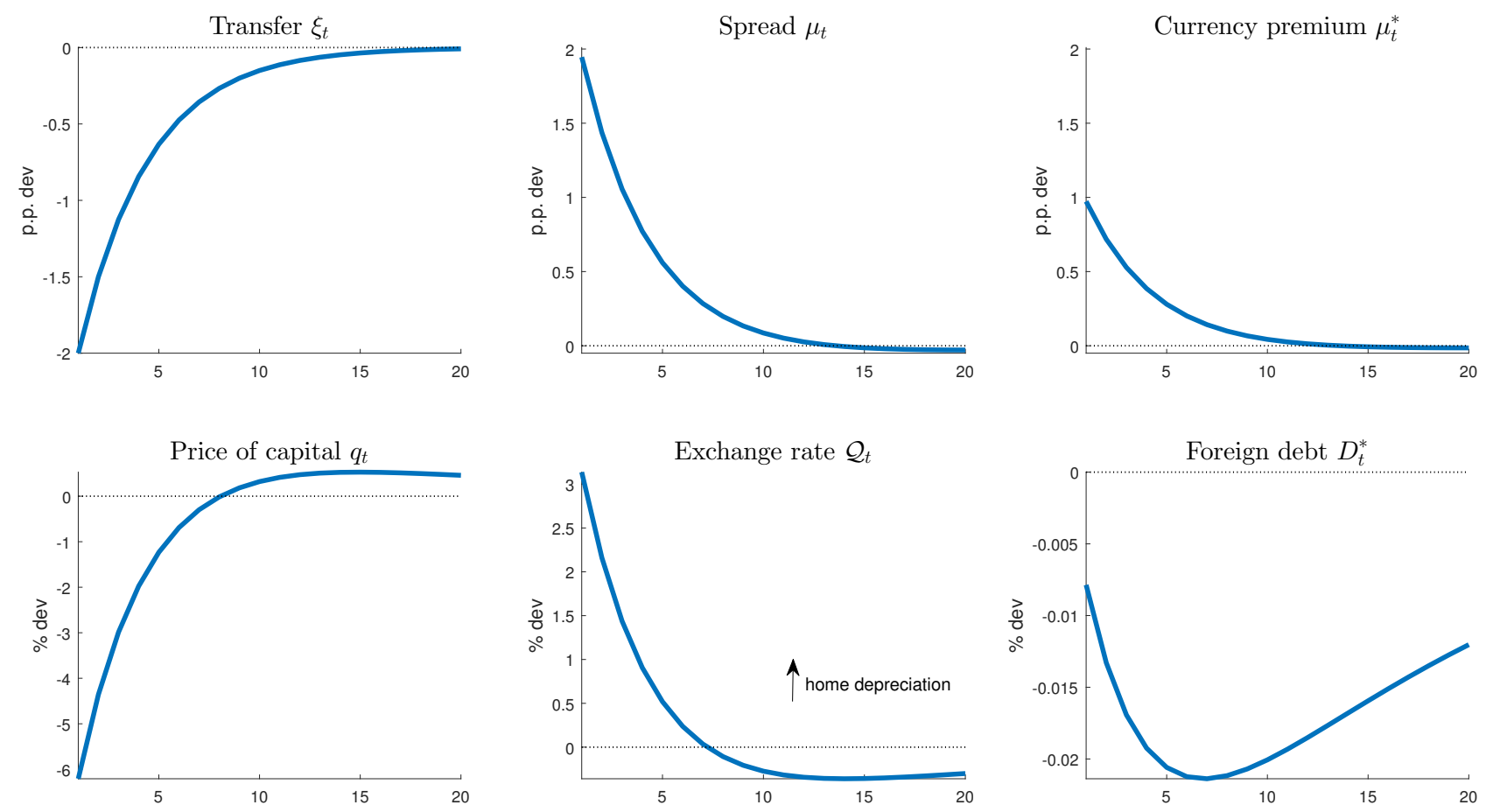

Parameter values: $\beta=0.9925, \beta^{*}=0.9975, \gamma=0.5, \theta=0.2, \xi=0.25, \chi_{m}=\chi_{x}=.25$

0.75 , implying a half-life of about a year. The spread $\mu_{t}$ rises by about the same amount of the drop in the transfer, and through the optimal loan portfolio condition the currency premium also rises - by about half as much as the spread, given that $\gamma=0.5$. The price of capital falls by six percent, and the domestic currency depreciates by three percent. Aggregate foreign borrowing $D_{t}^{*}$ falls persistently - a capital outflow. Once the effects of the lower $\xi_{t}$ begin to fade, note that the economy is left with a lower value of net foreign liabilities $D_{t}^{*}$ (the only endogenous state variable), which everything else equal works to improve the agency friction. This accounts for the rise in $q_{t}$ above steady state after about two years. For the same reason, $\mathcal{Q}_{t}$ falls below steady state (i.e. home appreciates) starting after two years. The appreciation then slowly erodes the net foreign asset position by reducing net exports, thus bringing $D_{t}^{*}$ slowly back up toward steady state.

The dynamics described above stand in contrast to what would obtain if $\gamma$ were zero, i.e. if the enforcement friction was equally severe for domestic as for foreign credit. In that case we would simply have that $\mu_{t}=\theta-\xi_{t}$ and $\mu_{t}^{*}=0$. Accordingly, a drop in $\xi_{t}$ would lead to a commensurate rise in $\mu_{t}$ and a fall in $q_{t}$, without any effect on the currency premium, the exchange rate, or the net foreign debt position. 


\section{$3 \quad$ Full Model}

The core model is a two-country extension of an open-economy New Keynesian model (for example, Gali and Monacelli (2005) and Erceg et al. (2007)) augmented with financing frictions as in Gertler and Kiyotaki (2010) or Gertler and Karadi (2011). Compared to the simple model in the previous section, we now allow banks to be long-lived. This introduces endogenous persistence in their net worth and, more importantly, allows it to be affected by movements in the exchange value of domestic currency (to the extent that part of banks' liabilities are in foreign currency). In addition, we augment the model with a standard set of nominal and real rigidities - including nominal price and wage stickiness, habit persistence in consumption, and adjustment costs in investment and in imports. These features help enhance the model's empirical realism.

\subsection{Banks}

We begin by describing the banker's problem in the full model. We first describe the evolution of banks' net worth, and then outline their optimization problem.

\subsubsection{Balance sheet and net worth evolution}

Banks' positive survival probability, $\sigma_{b}>0$, leads net worth to evolve endogenously, in contrast to the simple model described above. Exiting bankers are replaced by new entrants, which receive a small endowment in the form of fraction $\xi_{b}$ of the value of the capital stock. The balance sheet identity is

$$
\underbrace{q_{t} S_{i t}}_{\begin{array}{c}
\text { claims on } \\
\text { domestic firms }
\end{array}} \equiv \underbrace{D_{i t}}_{\begin{array}{c}
\text { domestic } \\
\text { deposits }
\end{array}}+\underbrace{\mathcal{Q}_{t} D_{i t}^{*}}_{\begin{array}{c}
\text { (real) dollar } \\
\text { deposits }
\end{array}}+\underbrace{N_{i t}}_{\begin{array}{c}
\text { net } \\
\text { worth }
\end{array}}
$$

The banker's budget constraint, expressed in (real) domestic currency, is

$$
q_{t} S_{i t}+R_{t} D_{i t-1}+R_{t}^{*} \mathcal{Q}_{t} D_{i t-1}^{*} \leq R_{k t} q_{t-1} S_{i t-1}+D_{i t}+\mathcal{Q}_{t} D_{i t}^{*}
$$

The left-hand side is bank $i$ 's uses of funds, including lending to non-financial firms $\left(q_{t} S_{i t}\right)$ plus deposit repayments (both domestic, $R_{t} D_{i t-1}$, and foreign, $R_{t}^{*} \mathcal{Q}_{t} D_{i t-1}^{*}$ ). The right-hand side is the source of funds, including returns from past loans (the first term) plus deposits issued (to domestic residents and to foreigners, second and third term respectively). 
Combining the two equations above yields the evolution of net worth:

$$
N_{i t}=\left(R_{k t}-R_{t}\right) q_{t-1} S_{i t-1}+\left(R_{t}-R_{t}^{*} \frac{\mathcal{Q}_{t}}{\mathcal{Q}_{t-1}}\right) \mathcal{Q}_{t-1} D_{i t-1}^{*}+R_{t} N_{i t-1}
$$

\subsubsection{Optimization problem}

The banker's objective is

$$
\begin{gathered}
V_{i t}=\max _{S_{i t}, D_{i t}, D_{i t}^{*}}\left(1-\sigma_{b}\right) \mathbb{E}_{t}\left[\Lambda_{t, t+1}\left(R_{k t+1} q_{t} S_{i t}-R_{t+1} D_{i t}-R_{t+1}^{*} \mathcal{Q}_{t+1} D_{i t}^{*}\right)\right] \\
+\sigma_{b} \mathbb{E}_{t}\left(\Lambda_{t, t+1} V_{i t+1}\right)
\end{gathered}
$$

subject to

$$
\begin{aligned}
q_{t} S_{i t} & =D_{i t}+\mathcal{Q}_{t} D_{i t}^{*}+N_{i t} \\
N_{i t+1} & =\left(R_{k t+1}-R_{t+1}\right) q_{t} S_{i t}+\left(R_{t+1}-R_{t+1}^{*} \frac{\mathcal{Q}_{t+1}}{\mathcal{Q}_{t}}\right) \mathcal{Q}_{t} D_{i t}^{*}+R_{t+1} N_{i t} \\
V_{t} & \geq \theta\left(1+\frac{\gamma}{2} x_{t}^{2}\right) q_{t} S_{i t} \quad(\mathrm{IC})
\end{aligned}
$$

where $x_{i t}=\mathcal{Q}_{t} D_{i t}^{*} / q_{t} S_{i t}$ and $\Lambda_{t, t+1}$ is household's real stochastic discount factor between $t$ and $t+1$. Compared to the simple model, here we assume that the default payoff is quadratic in the foreign funding ratio (rather than linear). This turns out to have some desirable properties, without affecting the qualitative insights obtained from the simpler linear case. In particular, the quadratic formulation implies an interior solution for each bank's foreign funding ratio.

\subsection{Employment agencies}

As in Erceg, Henderson and Levin (2000), there is a continuum of households indexed by $i \in[0,1]$, each of which is a monopolistic supplier of specialized labor $L_{i, t}$. A large number of competitive "employment agencies" combine specialized labor into a homogeneous labor input used by intermediate goods producers, according to

$$
L_{t}=\left[\int_{0}^{1} L_{i, t}^{\frac{1}{1+\theta_{w}}} d i\right]^{1+\theta_{w}}
$$


From employment agencies' cost minimization, demand for labor variety $i$ is

$$
L_{i, t}=\left(\frac{W_{i, t}}{W_{t}}\right)^{-\frac{1+\theta_{w}}{\theta_{w}}} L_{t}
$$

where $W_{i, t}$ is the nominal wage received by supplier of labor of type $i$ and the wage paid by goods producers is

$$
W_{t}=\left[\int_{0}^{1} W_{i, t}^{-\frac{1}{\theta_{w}}} d j\right]^{-\theta_{w}}
$$

\subsection{Domestic households and wage setting}

Household $i$ seeks to maximize

$$
\mathbb{E}_{0} \sum_{j=0}^{\infty} \beta^{j}\left(\frac{\sigma}{\sigma-1}\left(C_{t+j}-h C_{t+j-1}\right)^{\frac{\sigma-1}{\sigma}}-\frac{\chi_{0}}{1+\chi} L_{i, t+j}^{1+\chi}\right)
$$

subject to

$$
\begin{aligned}
P_{C t} C_{t}+P_{C t} D_{t} & \leq W_{i, t} L_{i, t}+P_{C t} R_{t} D_{t-1}+\mathcal{W}_{i t}+\Pi_{t} \\
C_{t} & =\left[(1-\omega)^{\frac{\rho}{1+\rho}} C_{D t}^{\frac{1}{1+\rho}}+\omega^{\frac{\rho}{1+\rho}}\left(\varphi_{C t} M_{C t}\right)^{\frac{1}{1+\rho}}\right]^{1+\rho} \\
P_{C t} & =\left[(1-\omega) P_{D t}^{-\frac{1}{\rho}}+\omega P_{M t}^{-\frac{1}{\rho}}\right]^{-\rho}
\end{aligned}
$$

Above, $C_{t}$ denotes the consumption basket, a CES aggregate of domestically-produced goods, $C_{D t}$, and imports, $M_{C t}$; $D_{t}$ is deposits in domestic banks, which pay real (i.e. in terms of the domestic basket) interest rate $R_{t} ; \mathcal{W}_{i t}$ is the net cash flow from household $i$ 's portfolio of state-contingent securities (used to ensure that all workers in the household consume the same amount $C_{t}$, despite earning different wage income); and $\Pi_{t}$ is total bank and firm profits distributed to the household. The variables $P_{D t}$ and $P_{M t}$ denote, respectively, the price of the domestically-produced good and the price of the imported good, and $P_{C t}$ is the price of the home basket (i.e. the CPI). We assume producer currency pricing (PCP): $P_{M t}=e_{t} P_{D t}^{*}$, where $e_{t}$ is the nominal exchange rate (i.e. the price of a dollar in terms of home currency). The parameter $h$, satisfying $0<h<1$, governs the extent of consumption habits.

Following Erceg, Guerrieri and Gust (2006) we assume costs of adjusting consumption 
imports, which take the following form:

$$
\varphi_{C t}=1-\frac{\varphi_{M}}{2}\left(\frac{M_{C t} / C_{D t}}{M_{C t-1} / C_{D t-1}}-1\right)^{2}
$$

This formulation of adjustment costs implies that it is costly to change the proportion of domestic and foreign goods in the aggregate consumption basket. As such, it dampens the short-run to response of the import share to movements in the relative price of imports, but allows the level of imports to respond quickly to changes in overall consumption $C_{t} \cdot{ }^{10}$

As in Erceg et al. (2000), fraction $\xi_{w}$ of households cannot set the wage but instead follows the indexation rule

$$
W_{i, t}=W_{i, t-1} \pi_{w t-1}^{\iota_{w}}, \pi_{w t} \equiv \frac{W_{t}}{W_{t-1}}
$$

The remaining fraction of households solves

$$
\max _{W_{t}^{o}} \mathbb{E}_{t}\left\{\sum_{j=0}^{\infty}\left(\xi_{w} \beta\right)^{j}\left[-\frac{\chi_{0}}{1+\chi} L_{i, t+j}^{1+\chi}+\frac{U_{C, t+j}}{P_{C t+j}} L_{i, t+j} W_{t}^{o} \prod_{k=1}^{j} \pi_{w t+k-1}^{\iota w}\right]\right\}
$$

subject to the labor demand function (22).

\subsection{Foreign (U.S.) households}

U.S. household's problem is analogous to that of domestic households:

$$
\max \mathbb{E}_{0} \sum_{j=0}^{\infty} \beta^{* j}\left(\frac{\sigma}{\sigma-1}\left(C_{t+j}^{*}-h C_{t+j-1}^{*}\right)^{\frac{\sigma-1}{\sigma}}-\frac{\chi_{0}{ }^{*}}{1+\chi} L_{i, t+j}^{*}{ }^{1+\chi}\right)
$$

subject to

$$
P_{C t}^{*} C_{t}^{*}+B_{t}^{*}+P_{C t}^{*} D_{t}^{*} \leq W_{i, t}^{*} L_{i, t}^{*}+R_{t}^{n *} B_{t}^{*}+P_{C t}^{*} \tilde{R}_{t}^{*} D_{t-1}^{*}+\Pi_{t}^{*}+\mathcal{W}_{i t}^{*}
$$

where $D_{t}^{*}$ is short-term deposits in home banks by U.S. households, $B_{t}^{*}$ is short-term nominal bonds (in zero net supply), $\tilde{R}_{t}^{*}$ is the real return received from deposits in banks of the home economy (in real dollars), and $R_{t}^{n *}$ is the Fed funds rate. We allow for the possibility of a

\footnotetext{
${ }^{10}$ As emphasized by Erceg et al. (2005), adjustment costs as modeled above permit the model to match the evidence described in Hooper et al. (2000) and in Mc Daniel and Balistreri (2003) that the short-run trade price elasticity is smaller than the long-run elasticity.
} 
$\operatorname{tax} \tau$ on home banks' foreign borrowing: $R_{t}^{*}=(1+\tau) \tilde{R}_{t}^{*}$. As explained below, we use this tax as a device to vary the steady-state amount of borrowing from the U.S. by home banks. U.S. households also face nominal wage rigidities and costs of adjusting imports, in a manner analogous to the description in the preceding section.

\subsection{Firms and price setting}

A continuum of mass unity of retail firms produce final output using intermediate goods as inputs. Final output $Y_{t}$ is a CES composite of retailers' output:

$$
Y_{t}=\left(\int_{0}^{1} Y_{i, t}^{\frac{1}{1+\theta_{p}}} d i\right)^{1+\theta_{p}}
$$

where $Y_{i, t}$ is output by retailer $i \in[0,1]$. Let the price set by home retailer $i$ be $P_{D i, t}$. The price level of final home output is $P_{D t}=\left[\int_{0}^{1} P_{D i, t}^{-\frac{1}{\theta_{p}}} d i\right]^{-\theta_{p}}$. Cost minimization by users of final output yields the following demand function for firm $i$ 's output:

$$
Y_{i, t}=\left(\frac{P_{D i, t}}{P_{D t}}\right)^{-\frac{1+\theta_{p}}{\theta_{p}}} Y_{t}
$$

Each firm can reset its price with probability $1-\xi_{p}$. Firms not resetting their price follow the indexation rule

$$
P_{D i, t}=P_{D i, t-1} \pi_{t-1}^{\iota_{p}}, \quad \pi_{t} \equiv P_{D t} / P_{D t-1}
$$

where $\pi_{t}$ is home-good inflation. The problem facing a firm resetting its price in period $t$ is thus

$$
\max _{P_{D t}^{o}} \mathbb{E}_{t} \sum_{j=0}^{\infty} \Lambda_{t, t+j} \xi_{p}^{j}\left(P_{D t}^{o} \prod_{k=1}^{j} \pi_{t+k-1}^{\iota_{p}}-M C_{t+j}\right) Y_{i, t+j}
$$

The production function of each intermediate goods firm $i$ is given by $Y_{i, t}=K_{i, t}^{\alpha} L_{i, t}^{1-\alpha}$. 


\subsection{Capital producers}

Capital producers produce new capital goods subject to costs of adjusting the level of investment $I_{t}$ given by

$$
\phi_{I t}=\frac{\psi_{I}}{2}\left(\frac{I_{t}}{I_{t-1}}-1\right)^{2} I_{t}
$$

(in units of the home good). The objective of the representative capital producer is to choose a state-contingent sequence $\left\{I_{t+j}\right\}_{j=0}^{\infty}$ to maximize the expected discounted value of profits:

$$
\mathbb{E}_{t}\left\{\sum_{j=0}^{\infty} \Lambda_{t, t+j}\left[q_{t+j} I_{t+j}-\frac{P_{D t+j}}{P_{C t+j}} \phi_{I t+j}\right]\right\}
$$

where $q_{t}$ denotes the real price of capital goods (in terms of the home basket). As in the case of consumption goods, investment goods are a composite of domestic $\left(I_{D t}\right)$ and imported $\left(M_{I t}\right)$ goods, also subject to costs of adjusting the imported-domestic good mix:

$$
I_{t}=\left[(1-\omega)^{\frac{\rho}{1+\rho}} I_{D t}^{\frac{1}{1+\rho}}+\omega^{\frac{\rho}{1+\rho}}\left(\varphi_{I t} M_{I t}\right)^{\frac{1}{1+\rho}}\right]^{1+\rho}
$$

with

$$
\varphi_{I t}=1-\frac{\varphi_{M}}{2}\left(\frac{M_{I t} / I_{D t}}{M_{I t-1} / I_{D t-1}}-1\right)^{2}
$$

Optimality with respect to the investment aggregate $I_{t}$ gives rise to an investment- $q$ relation:

$$
\begin{array}{r}
q_{t}=1+p_{D t} \phi\left(\frac{I_{t}}{I_{t-1}}-1\right) \frac{I_{t}}{I_{t-1}}+p_{D t} \frac{\phi_{I}}{2}\left(\frac{I_{t}}{I_{t-1}}-1\right)^{2} \\
-\mathbb{E}_{t}\left\{\Lambda_{t, t+1} p_{D t+1} \phi\left(\frac{I_{t+1}}{I_{t}}-1\right)\left(\frac{I_{t+1}}{I_{t}}\right)^{2}\right\}
\end{array}
$$

where $p_{D t} \equiv P_{D t} / P_{C t}$. 


\subsection{Domestic market clearing, BOP, and monetary policy rule}

The market clearing condition for the home good is as follows:

$$
Y_{t}=C_{D t}+I_{D t}+\frac{\xi_{f}}{\xi_{h}}\left(M_{C t}^{*}+M_{I t}^{*}\right)+\phi_{I t}
$$

where $\frac{\xi_{f}}{\xi_{h}}$ is the relative population size of the foreign economy (note that all variables are expressed in per capita terms). The balance of payments, obtained by aggregating the budget constraints of agents in the home economy, is given by

$$
\mathcal{Q}_{t}\left(D_{t}^{*}-R_{t}^{*} D_{t-1}^{*}\right)=C_{t}+I_{t}+p_{D t} \phi_{I t}-p_{D t} Y_{t}
$$

As a baseline case, we assume that monetary policy in the home country follows an inertial Taylor rule:

$$
R_{t}^{n}=\left(R_{t-1}^{n}\right)^{\gamma_{r}}\left(\bar{R} \pi_{t}^{\gamma_{\pi}}\right)^{1-\gamma_{r}} \varepsilon_{t}^{r}
$$

where $\pi_{t} \equiv P_{D t} / P_{D t-1}$ is domestic inflation. Later we consider an alternative policy rule which allows for an exchange rate stabilization motive. Monetary policy in the U.S. is conducted according to an inertial Taylor rule as specified by Justiniano et al. (2010) which, in addition to inflation, includes the output gap (both in levels and in growth rates) as an argument.

\section{Model Analysis}

\subsection{Calibration}

Table 1 reports parameter values. We calibrate the U.S. discount factor, $\beta^{*}$, to 0.9975 , implying a steady-state real interest rate of $1 \%$ per year. This choice follows several recent studies (e.g. Reifschneider (2016)) and is motivated by estimates indicating a decline in the U.S. natural rate (see, for example, Holston, Laubach and Williams (2017)). To calibrate the home discount factor, we rely on estimates of Mexico's long-run natural rate from Carrillo et al. (2017) of about 3 percent, and accordingly calibrate $\beta$ to $0.9925 .{ }^{11}$

\footnotetext{
${ }^{11}$ Magud and Tsounta (2012) also estimate the natural rate for several Latin American countries using various methodologies. Averaging across methodologies yields a range of values between 2 and 5 percent across countries, with a cross-country average of about 3 percent.
} 
The intertemporal elasticity of substitution $(\sigma)$, capital share $(\alpha)$ and capital depreciation rate $(\delta)$ are calibrated to the conventional values of $1,0.33$, and 0.025 , respectively. We also calibrate the steady-state wage and price markup to 20 percent, a conventional value. For the remaining parameters governing features of the domestic economy, we rely on estimates from Justiniano et al. (2010). These parameters include the degree of consumption habits $(h)$, the inverse Frisch elasticity of labor supply $(\chi)$, the parameters governing price and wage rigidities $\left(\theta_{p}, \xi_{p}, \theta_{w}\right.$, and $\left.\xi_{w}\right)$, and the investment adjustment cost parameter $\left(\Psi_{I}\right)$. The values for these parameters are listed in the top part of Table 1. We also rely on Justiniano et al. (2010) to calibrate the parameters for the U.S. Taylor rule $\left(\gamma_{r}^{*}, \gamma_{\pi}^{*}, \gamma_{x}^{*}\right.$ and $\gamma_{d x}^{*}$, where the latter two parameters govern the response to the output gap and to output gap growth, respectively). Turning to the baseline home policy rule, we set $\gamma_{\pi}$ to the conventional value of 1.5. Aside from the policy rule and the discount factor, all other parameters are set symmetrically across the two countries.

Turning to parameters governing international trade, we follow Erceg et al. (2007) (who rely on estimates by Hooper et al. (2000)) and set the trade price elasticity $\frac{1+\rho}{\rho}$ to 1.5 . We set $\omega=0.20$, which implies a steady-state exports-to-GDP ratio of 28 percent - a value in the neighborhood of that observed for emerging economies like Mexico or Turkey. We set the population size of the home economy to one fifth that of the U.S. The trade adjustment cost parameter $\varphi_{M}$ is set to 10, as in Erceg et al. (2006) and Erceg et al. (2005). This value implies a price elasticity of slightly below unity after four quarters, consistent with the evidence that the short-run elasticity is lower than the long-run one.

Regarding the parameters governing the financial friction, we set the survival rate $\sigma_{b}$ to 0.969 , implying an expected horizon of 8 years. To remaining three parameters are set to hit three targets: a steady-state credit spread of 150 basis points annually, a leverage ratio of 5 , and a ratio of foreign-currency debt to total debt of 30 percent (conditional on the tax on foreign borrowing, $\tau$, being set to zero). The target for the credit spread reflects the average value of $\mathrm{BBB}$ corporate bond spreads in emerging economies. The target leverage ratio is a rough average of leverage across different sectors. Leverage ratios in the banking sector are typically greater than five, ${ }^{12}$ but the corporate sector features a much lower ratio of assets to equity (between two and three in emerging markets ${ }^{13}$ ). Our target of five reflects a rough compromise between these two values. Finally, evidence in Goldstein and Turner (2004) and

\footnotetext{
${ }^{12}$ For example, bank assets to capital averaged around 10 for Mexico in recent years. Source: IMF Global Financial Stability Report.

${ }^{13}$ See e.g. IMF Global Financial Stability Report October 2015, Chapter 3.
} 
Table 1: Calibration

\begin{tabular}{lcc} 
Parameter & Symbol & Value \\
\hline Home discount factor & $\beta$ & 0.9925 \\
U.S. discount factor & $\beta^{*}$ & 0.9975 \\
IES & $\sigma$ & 1 \\
Habit parameter & $h$ & 0.78 \\
Inverse Frisch elasticity of labor supply & $\chi$ & 3.79 \\
Trade price elasticity & $\frac{1+\rho}{\rho}$ & 1.5 \\
Trade openness & $\omega$ & 0.2 \\
Relative home size & $\xi_{h} / \xi_{f}$ & 0.2 \\
Trade adjustment cost parameter & $\varphi_{M}$ & 10 \\
Capital share & $\alpha$ & 0.33 \\
Capital depreciation & $\delta$ & 0.025 \\
Prob. of keeping price fixed & $\xi_{p}$ & 0.84 \\
Price indexation & $\xi_{p}$ & 0.24 \\
Price markup & $\theta_{p}$ & 0.2 \\
Prob. of keeping wage fixed & $\xi_{p}$ & 0.70 \\
Wage indexation & $\xi_{p}$ & 0.15 \\
Wage markup & $\theta_{p}$ & 0.2 \\
Investment adjustment cost & $\Psi_{I}$ & 2.85 \\
\hline Home Taylor rule & $\gamma_{r}$ & 0.82 \\
& $\gamma_{\pi}$ & 1.50 \\
US Taylor rule & $\gamma_{r}^{*}$ & 0.82 \\
& $\gamma_{\pi}^{*}$ & 2.09 \\
& $\gamma_{x}^{*}$ & 0.07 \\
& $\gamma_{d x}^{*}$ & 0.24 \\
\hline Bank survival rate & $\sigma_{b}$ & 0.969 \\
Bank fraction divertable & $\theta$ & 0.57 \\
Bank transfer rate & $\xi_{b}$ & 0.02 \\
Home bias in bank funding & $\gamma$ & 6 \\
\hline
\end{tabular}

Chui, Kuruc and Turner (2016) on ratios of foreign-currency debt to total debt in emerging markets suggests an upper bound for this ratio of about 30 percent, justifying our target when $\tau=0$. These targets imply $\theta=57, \xi_{b}=0.02$, and $\gamma=6$.

One of our goals in the analysis below is to illustrate how the dynamics following various shocks differ depending on the degree of currency mismatch in the economy when the shock hits. To this end, we consider three different values for $\tau$ : a high value (of 160 basis points annually) which induces a steady-state foreign debt ratio of 5 percent, a value in the lowest range across emerging economies; an intermediate value (50 basis points) which implies a 
foreign debt ratio of 18 percent, a moderate value in light of the evidence; and finally a very low value of $\tau$ just 20 basis points, leading to a high value for the foreign debt ratio (25 percent).

\subsection{Drop in aggregate net worth}

We begin by illustrating the effects of a drop in aggregate bank net worth, an exercise analogous to that performed earlier in the context of the simple model. Specifically, we document the effects of a one-time transfer of wealth from bankers to households (think of a tax levied on banks' equity, the proceeds of which are distributed lump-sum back to households). The transfer is sized to 5 percent of steady-state net worth. The effects of the drop in net worth are shown in Figure 2.

Starting with the case in which the degree of currency mismatch is low (light blue dashed line), note that the dynamic responses of the credit spread, the currency premium, the price of capital, $q$, and the real exchange rate, $\mathcal{Q}$, resemble the responses highlighted by the simple model. For example, zooming in the real exchange rate response reveals that this variable rises (i.e., the home real exchange rate depreciates) by about 15 basis points on impact, and remains elevated for about eight quarters before turning negative and gradually converging back to zero from below. This dynamic pattern resembles the one obtained from the simpler model from Section 1. There are, however, some notable differences with respect to the simple model. Note, first, that now the drop in net worth is persistent, even though the transfer shock is transient. This reflects the fact that bankers are long-lived. Second, note that the net worth drops by over 10 percent on impact, i.e. twice the size of the transfer. This is the result of the financial accelerator effect working through a general-equilibrium decline in the asset price $q$ : lower aggregate net worth lowers investment and $q$, and the $q$ works to diminish net worth further. Notably, in contrast to the simple model, now the drop in net worth has adverse consequences for the real economy: aggregate investment falls by about 3 percent, leading output to fall despite a modest rise in exports.

The exchange rate depreciation in the experiment just described is, however, quantitatively small, as the currency premium rises only modestly (about 20 basis points). As the degree of currency mismatch rises, however, the self-reinforcing feedback between a depreciating currency and declining net worth becomes stronger: from equation (21), note that a realized depreciation (high $\mathcal{Q}_{t} / \mathcal{Q}_{t-1}$ ) lowers $N_{i t}$, with the magnitude of this effect larger the 
Figure 2: One-time drop in aggregate bank net worth
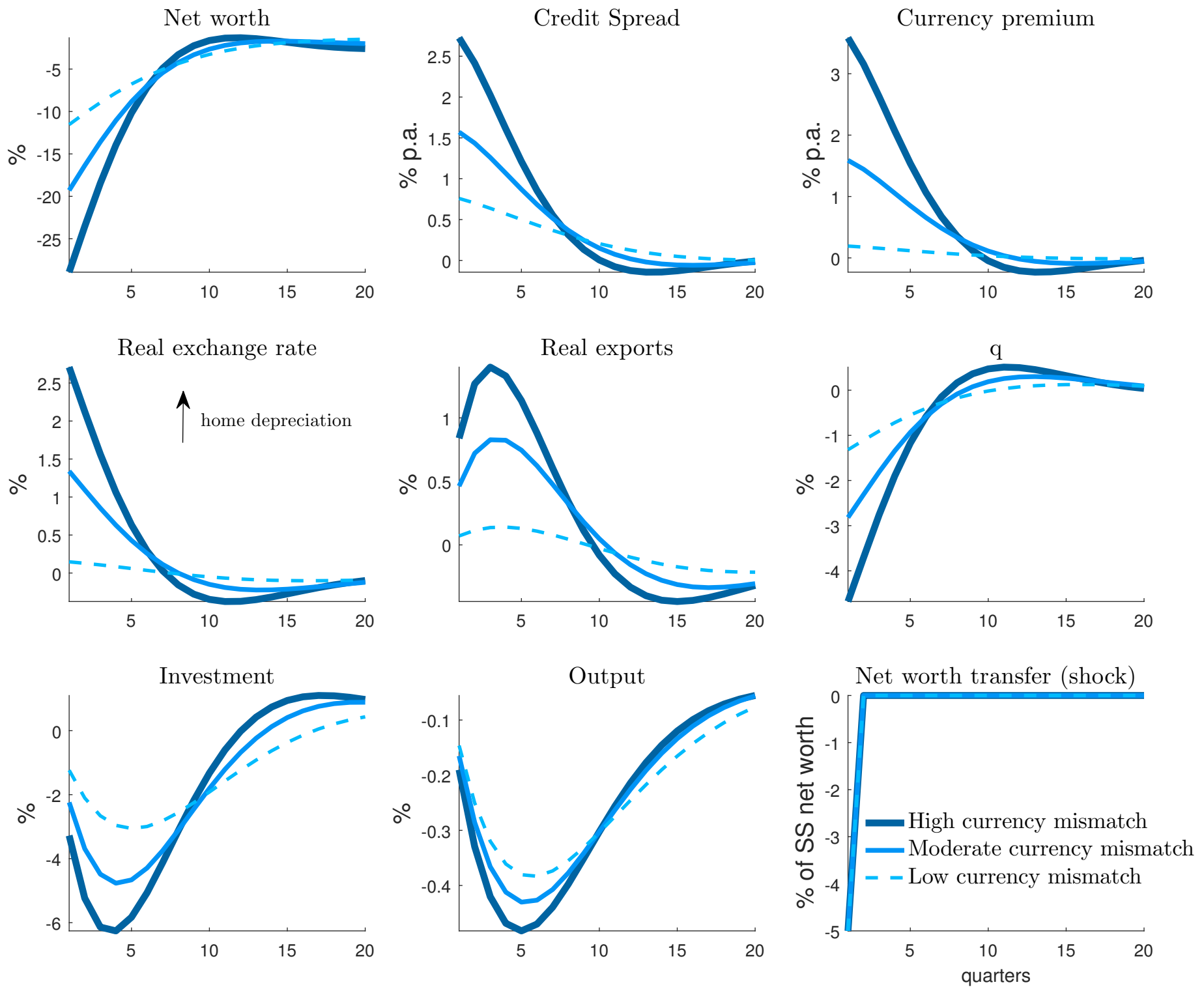

Note: The Figure shows the effects of one-time net worth transfer from bankers to households (sized at 5 percent of steady-state net worth) when the currency mismatch in the economy is low (light blue dashed line), moderate (blue solid line), and high (dark blue solid line). All variables shown relative to steady state. 
greater the amount of foreign debt. ${ }^{14}$ Thus, the adverse feedback loop between net worth and currency movements becomes more powerful when banks' balance sheets feature a larger degree of currency mismatch, as made clear by comparing the solid blue (moderate currency mismatch) and the dark blue solid line (high currency mismatch) to the light blue dashed line. In the high currency mismatch case, net worth falls by over 25 percent on impact, more than five times the size of the transfer shock. The currency premium skyrockets, and the real exchange rate depreciates about 2.5 percent. Because the credit spread $\mathbb{E}\left(R_{K}-R\right)$ also rises much more than with low currency mismatch, the fall in investment is much more severe - about twice as large - which pushes output down to a greater degree. At the same time, the larger depreciation implies a larger rise in exports, which provides some offset in the response of output. Still, output drops by about ten basis points more in the high currency mismatch case, relative to the case with low currency mismatch.

\subsection{Spillovers from U.S. tightening}

We begin by reviewing the spillovers from a tightening of U.S. monetary policy in a setting with frictionless financial markets, shown in Figure 3. For this exercise we assume a symmetric calibration of the two countries (i.e. similar country size, discount factor, and Taylor rule) although the main insights carry over to the asymmetric case. The effects of a U.S. monetary tightening on the home economy reflect two distinct channels often emphasized in the literature: an expenditure-switching channel arising due to the induced depreciation of the home terms of trade, which leads consumers and firms to substitute away from U.S. goods and into home goods, and an expenditure-reducing channel arising from the overall demand contraction due to higher real interest rates. We capture the expenditure-switching effect by setting $h \rightarrow 1$ and $\phi_{I} \rightarrow \infty$, implying that consumers and firms (both at home and abroad) keep aggregate consumption and investment constant. The resulting output movements reflect solely the switching from U.S. into home goods, and thus lead home output to rise by around 15 basis points and U.S. output to fall by the same amount. By contrast, the expenditure-reducing channel (captured by setting $\varphi_{M}$ to a very high value, which implies that agents do not alter the share of imports in total consumption or investment despite the relative price change) implies a reduction in home output of around 20 basis points. The net effect (the gray line with asterisks) reflects the combination of these

\footnotetext{
${ }^{14}$ The elasticity of net worth to a real depreciation is given by $\frac{\sigma^{b}}{\beta^{*}} \frac{\mathcal{Q} D^{*}}{N}$ (where letters without subscripts indicate steady-state values), and hence rises as the ratio of foreign debt to net worth increases.
} 
Figure 3: U.S. monetary tightening, frictionless economy
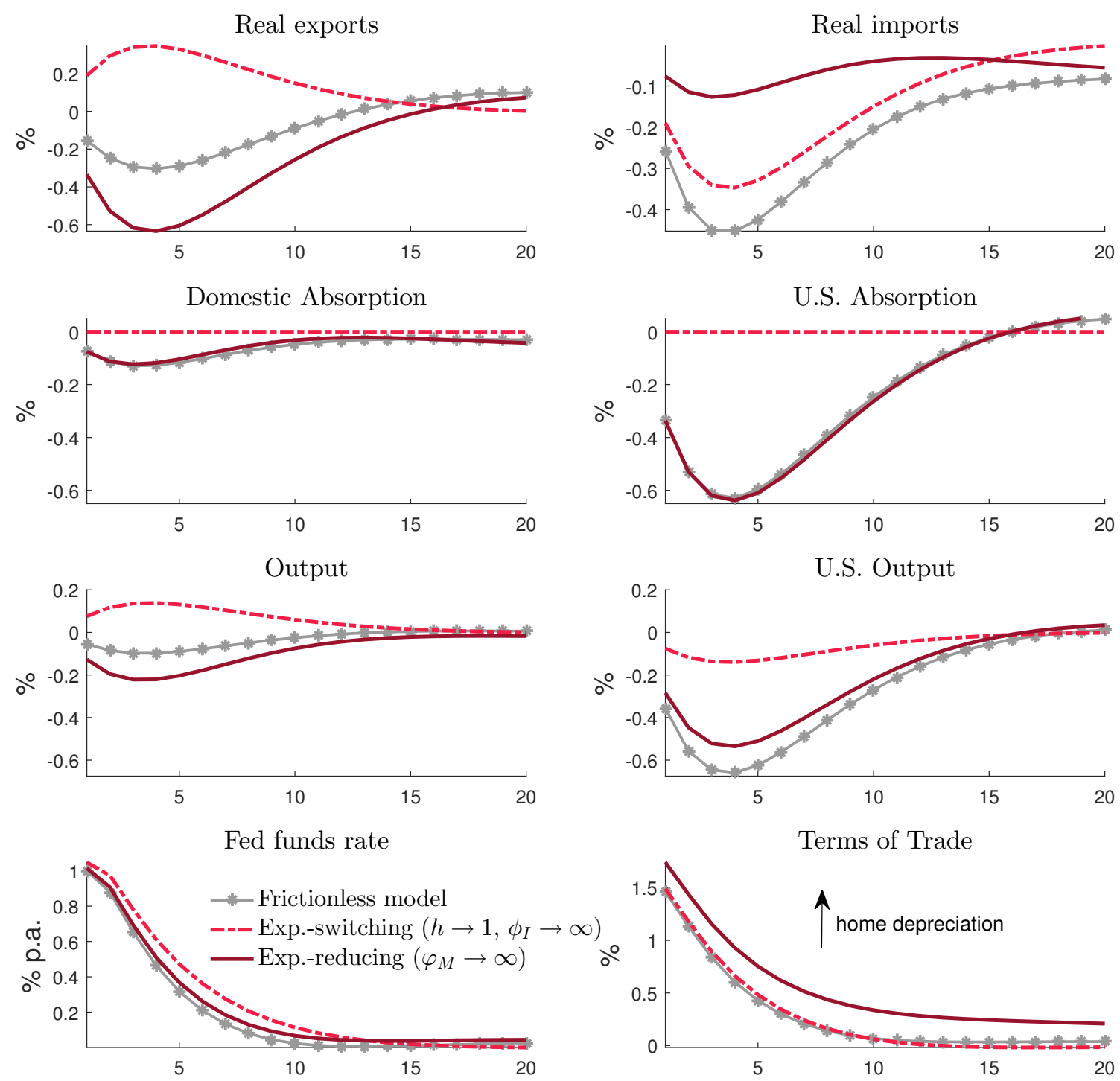

Note: The gray line with asterisks shows the effects of a U.S. monetary tightening in an economy without financial frictions and with the parameters calibrated symmetrically. The red dashed line sets the habit parameter $h$ very close to 1 and the investment adjustment cost parameter $\phi_{I}$ to a very high value. The dark red solid line sets the trade adjustment cost parameter to a very high value (and $h$ and $\phi_{I}$ back to their baseline values). All variables shown relative to steady state.

two forces: home output still declines as the expenditure-reducing channel is somewhat more powerful, but the drop is quantitatively modest.

We now examine spillovers under our baseline model with financial frictions, shown in Figure 4. When the degree of currency mismatch is low (light blue dashed line), the drop in 
Figure 4: U.S. monetary tightening, economy with frictions
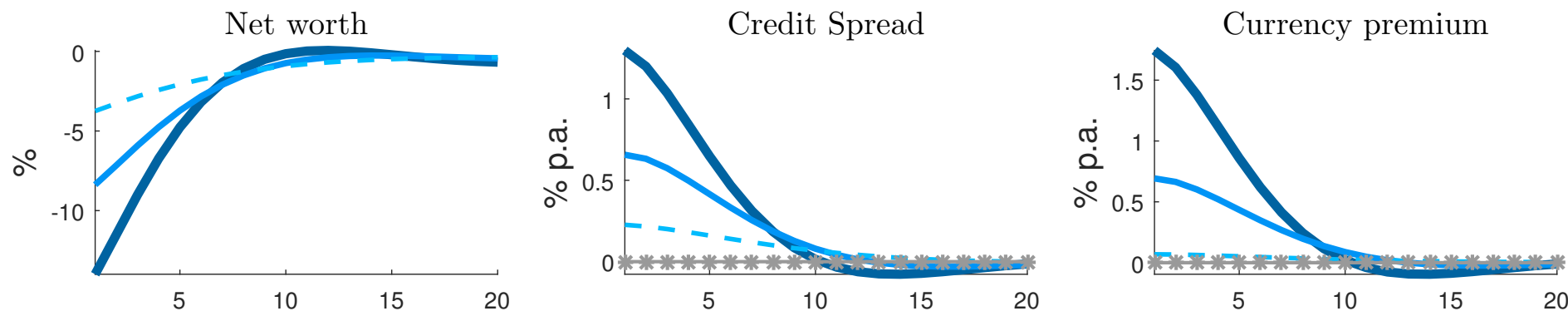

Real exchange rate
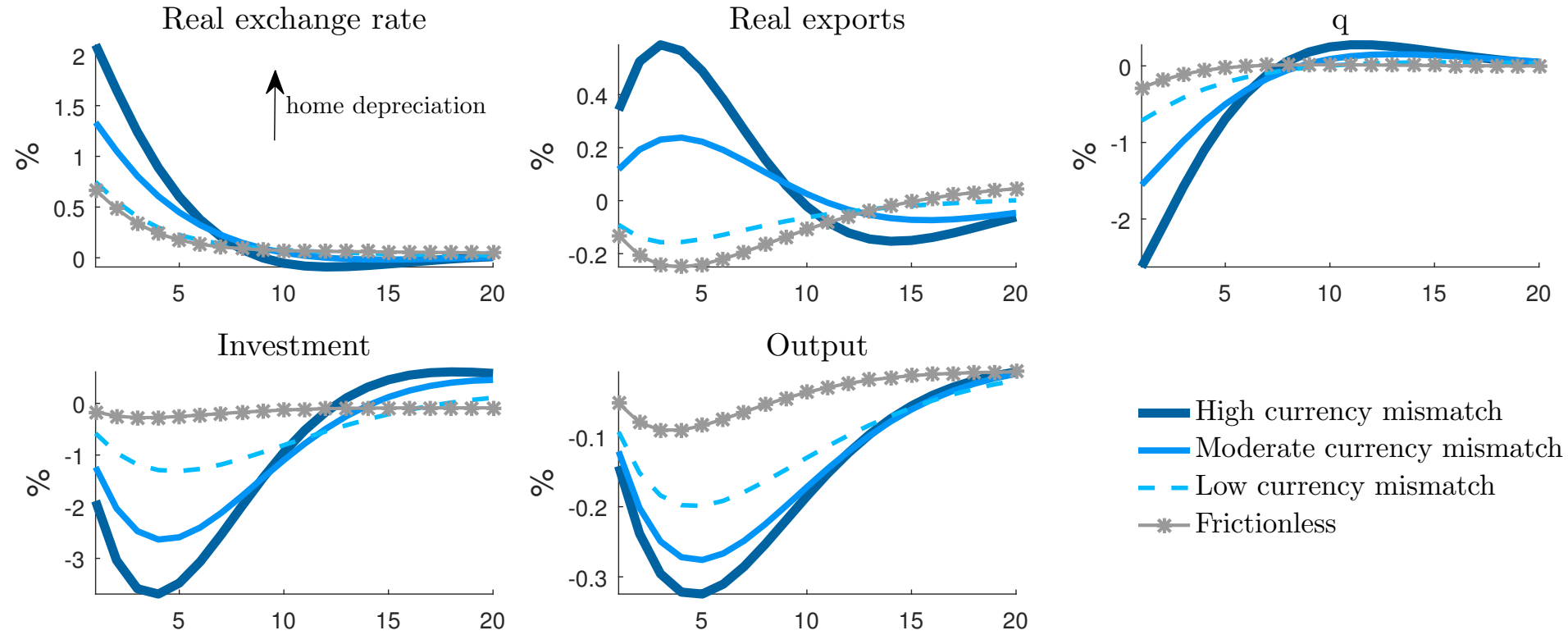

Fed funds rate
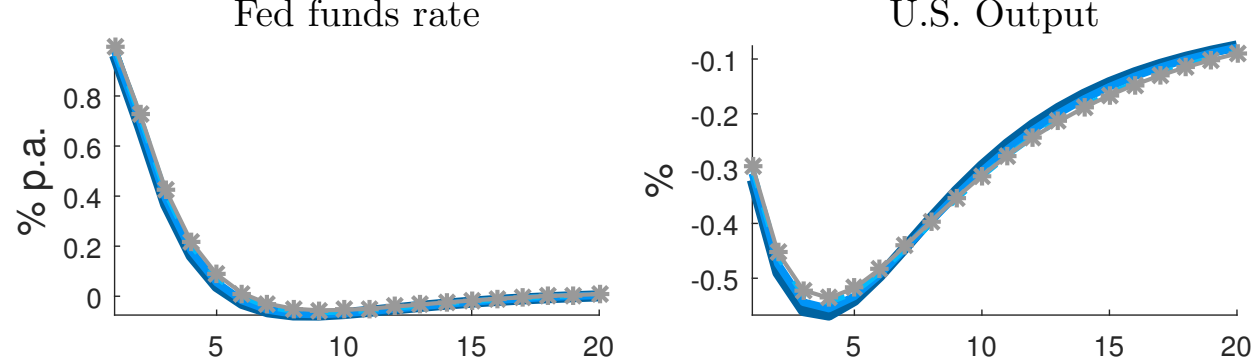

Note: The Figure shows the effects of a U.S. monetary tightening in the economies with high, moderate, and low currency mismatch (dark blue solid, blue solid, and light-blue-dashed lines respectively). The gray line with asterisks reports the effects in a frictionless economy. All variables shown relative to steady state. 
$q$ now initiates a decline in banks' net worth, leading credit spreads to rise modestly. As a consequence, investment now falls significantly more than in the frictionless economy. The lower bank net worth also induces a small rise in the currency premium, and the nominal and real exchange rate depreciate by somewhat more as a consequence. This leads exports to fall a little less than in the frictionless case. Still, the larger drag from investment on real activity dominates, and leads output to fall noticeably more than in the economy without financial frictions.

The spillovers from U.S. monetary tightening are significantly larger with a high degree of currency mismatch (dark blue solid line). The self-reinforcing feedback between currency movements and net worth is now much stronger, magnifying the response of financial variables: spread and currency premium rise by more, net worth and $q$ fall more steeply, and the real exchange rate depreciates by more. The end result is a 15 percent drop in net worth, three times that in the low degree of currency mismatch, and a depreciation of the real exchange rate of 2 percent, almost four times as much as the low currency mismatch case. The decline in investment is much larger as well-more than 3 percent, and even larger than the decline in U.S. investment (not shown). As a result, home output drops more than 0.30 percent - three times as much as in the frictionless economy. The drop in home output is more than half the U.S. decline, and is more persistent. Thus, a high degree of currency mismatch in domestic balance sheets works to significantly enhance the spillover effects of U.S. monetary tightening.

\subsubsection{Spillovers from U.S. tightening under Dominant Currency Pricing}

In this section we investigate U.S monetary policy spillovers under the dominant currency pricing (DCP) assumption. Our baseline model features producer currency pricing (PCP), in which exchange rate changes are fully passed through to import prices. As a result, the baseline model incorporates significant expenditure-switching effects (i.e., consumers switch away from US-produced goods, and toward home-produced goods, following a dollar appreciation). However, recent empirical evidence suggests that the vast majority of trade is invoiced in a small number of dominant currencies, with the U.S. dollar playing an important role (see, for example, Goldberg and Tille (2008), Gopinath (2016) and Casas et al. (2016)). In the case of DCP, one would expect the benefits to the home economy (in a context of tightening US monetary policy) through expenditure-switching channels to be weaker than under PCP.

In order to investigate the consequences of DCP for the U.S. monetary policy spillovers, 
Figure 5: U.S. monetary tightening, PCP vs DCP

\section{PCP}
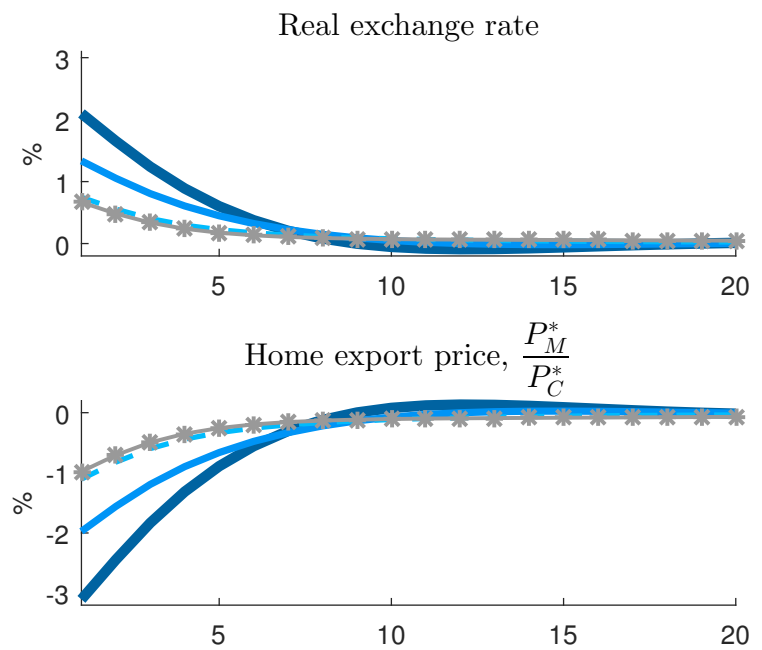

Real exports

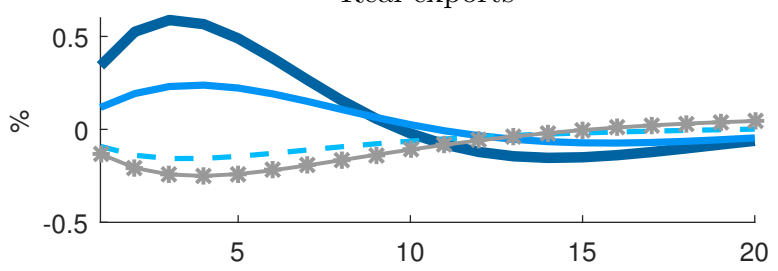

Output

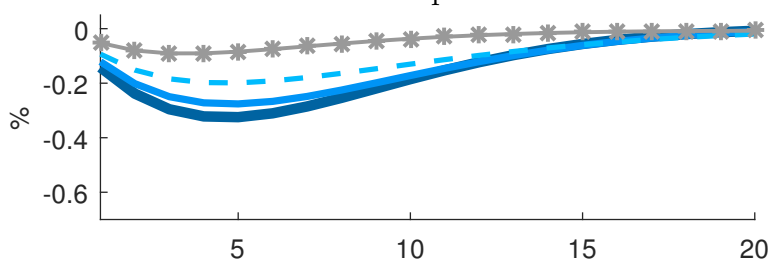

U.S. Output

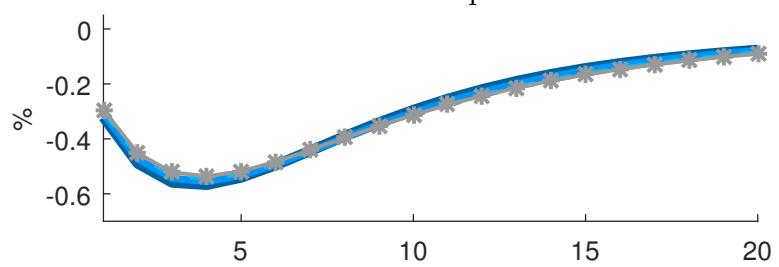

DCP
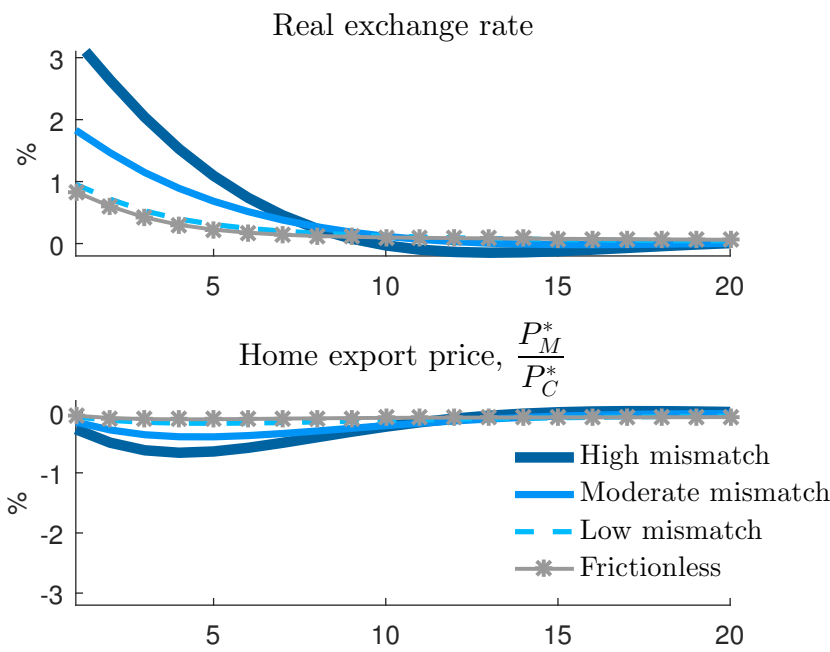

Real exports
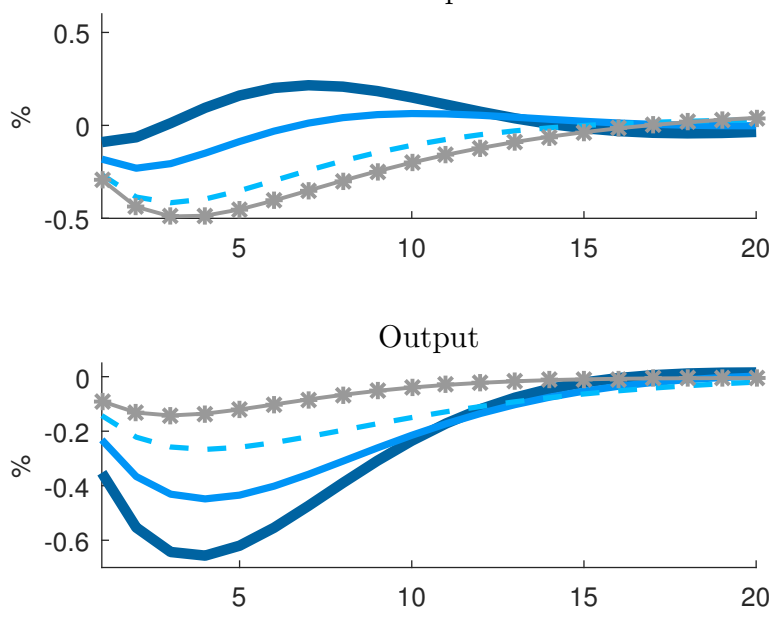

U.S. Output

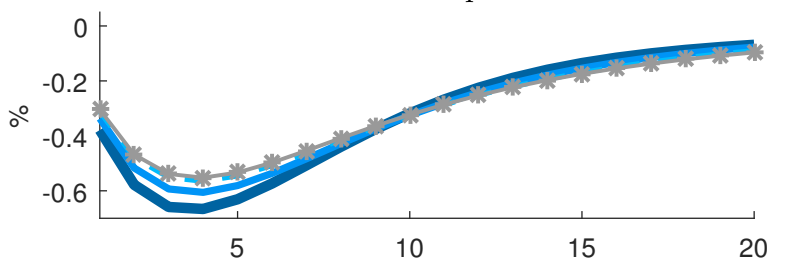

Note: The Figure shows the effects of a U.S. monetary tightening in the economies with high, moderate, and low currency mismatch (dark blue solid, blue solid, and light-blue-dashed lines respectively) under producer currency pricing (PCP) and dominant currency pricing (DCP). The gray line with asterisks reports the effects in a frictionless economy. All variables shown relative to steady state. 
we modify our model such that firms set export prices in the dominant currency (the U.S. dollar) and change them infrequently, similar to domestic prices. The simulation results are in Figure 5. We continue to consider monetary spillovers with different degrees of currency mismatches in balance sheets. For reference, the results under PCP are also shown in Figure 5 (left panel).

Starting with the case of frictionless financial markets (as shown by gray line with asterisks), note that under PCP, the exchange rate depreciation due to U.S. monetary tightening is fully passed through to home export prices, leading to a lower (real) export price of the home good, $P_{M t}^{*} / P_{C}^{*}$. By contrast, the movement in export prices under DCP is very small, leading to a larger decline in home's real exports.

The DCP assumption has important implications for the degree of amplification due to balance sheet mismatches. The reason is that under DCP, an exchange rate depreciation has little benefit in terms of greater exports, while it continues to entail significant financial tightening (and hence a reduced domestic absorption due to lower investment). As a result, the financial channel of spillovers turns significantly power powerful under DCP: note that under DCP, the magnitude of the output drop increases by more with greater balance-sheet mismatch. In the case of high mismatch, the U.S. monetary policy shock leads to a drop in home output of roughly the same size as the output decline in the U.S.

\subsection{Domestic monetary regimes}

The goal of this section is to explore the consequences of monetary regimes that allow for exchange rate stabilization motives. To build intuition, we begin by documenting the transmission from domestic monetary policy shocks to the exchange rate. Figure 6 shows the responses to a 1 percent rise in the domestic policy rate. For comparison, we include the responses in an economy without financial frictions (shown by the gray line with asterisks). In the frictionless case, the monetary shock induces a small decline in asset prices, and the currency appreciates by about 1.5 percent on impact.

In the low currency mismatch case (light blue dashed line), the financial accelerator effect kicks in. The economy suffers an increase in the currency premium, amid falling net worth and rising credit spreads. Interestingly, the domestic currency now appreciates a little less in the short run compared to the frictionless economy. The reason, of course, is the rise in the currency premium, resulting from the drop in bank net worth. Still, the effect of the latter on the exchange rate is relatively small. The adverse effect on the currency premium induced 
Figure 6: Domestic monetary tightening
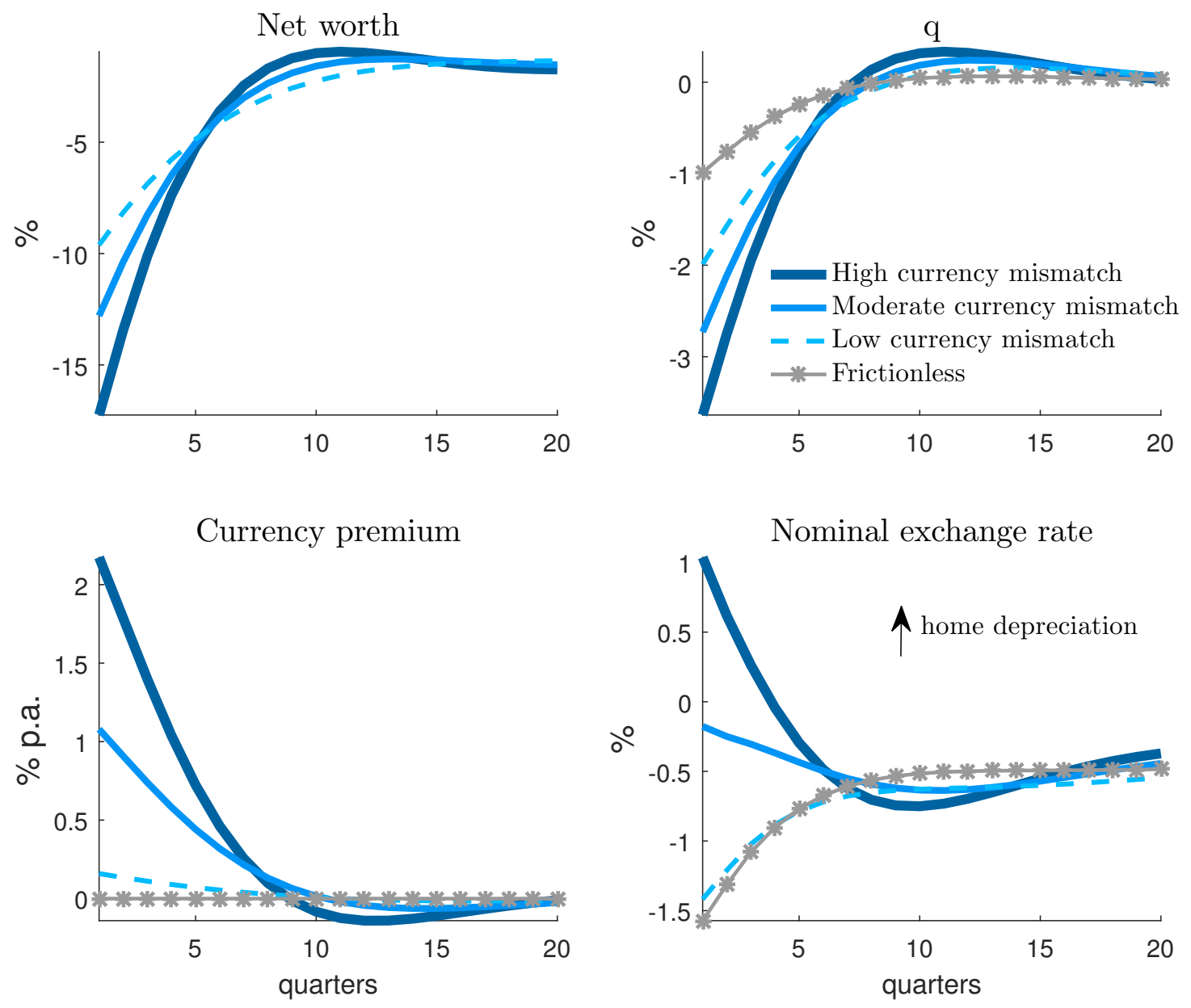

Note: The Figure shows the effects of a domestic monetary tightening in a frictionless economy (gray line with asterisks), and in the economies with low, moderate, and high currency mismatch (light blue dashed, blue solid, and dark blue solid lines, respectively). All variables shown relative to steady state.

by a domestic monetary tightening becomes much larger in the moderate (blue solid line) and high (dark blue solid line) currency mismatch economies. In the latter case the rise in the currency premium is enormous, more than 200 basis points annually. As a consequence, the real exchange rate now depreciates on impact, and remain depreciated in the short run (for about 4 quarters). Thus, and in sharp contrast to standard monetary models (e.g. Gali and Monacelli (2005)), a hike in the policy rate leads to a weaker currency in the short run.

We now turn to the question of whether a high degree of banks' currency mismatch provides grounds for a domestic monetary policy which attempts to stabilize (to some extent) 
the nominal exchange rate (NER henceforth). We are interested in this question because balance-sheet currency mismatches are often highlighted as the primary reason why policymakers in many emerging markets favor managing the exchange rate (e.g. Reinhart (2000)). To this end, we assume that domestic monetary policy is described by an interest rate rule that includes NER:

$$
\begin{aligned}
R_{t}^{n} & =\left(R_{t-1}^{n}\right)^{\gamma_{r}}\left(R_{t}^{n T}\right)^{1-\gamma_{r}} \varepsilon_{t}^{r} \\
R_{t}^{n T} & =\frac{1}{\beta} \pi_{t}^{\frac{1-\gamma_{e}}{\gamma_{e}}}\left(\frac{e_{t}}{e}\right)^{\frac{\gamma_{e}}{1-\gamma_{e}}}
\end{aligned}
$$

where $\gamma_{e} \in[0,1]$, i.e., the central bank in the domestic economy is assumed to respond to the NER in addition to domestic inflation, and higher values of $\gamma_{e}$ represent cases in which the exchange rate stabilization motive of the central bank is more important. ${ }^{15}$ This specification nests the two polar cases of strict inflation targeting (when $\gamma_{e}=0$ ) and an exchange rate $\operatorname{peg}\left(\gamma_{e}=1\right)$, and allows the parameterization of hybrid regimes of managed exchange rates.

Figure 7 displays the standard deviations of output, inflation and nominal exchange rate depreciation in an economy with low degree of currency mismatch (light blue dashed line) and with moderate degree of currency mismatch (blue solid line) for different values of $\gamma_{e}$. The economy with low degree of currency mismatch has the lowest output and inflation volatility for the smallest value of $\gamma_{e}$, which in turn entail highest exchange rate volatility (as in Gali and Monacelli (2005)). The same result holds in an economy with moderate degree of currency mismatch, but with one important difference: As the coefficient on the NER in the policy rule increases, the implied volatility of output and inflation now rise much faster, while the benefit in terms of lower NER volatility becomes much smaller (as the curve in the rightmost plot flattens out when the degree of mismatch rises). This finding suggests that conditional on U.S. monetary policy shocks, the desirability of gearing domestic monetary policy toward stabilizing the NER may actually diminish with the degree of currency mismatch in balance sheets, as the gains in terms of NER stability turn smaller at larger costs in terms of output and inflation instability.

Figure 8 provides a complementary perspective to the finding just described by showing the effects of a U.S. monetary tightening under different policy regimes in economies with low, moderate, and high degrees of currency mismatch (shown in the upper, middle, and

\footnotetext{
${ }^{15}$ We take this formulation from Gali and Monacelli (2016).
} 
Figure 7: Standard deviations and different monetary regimes
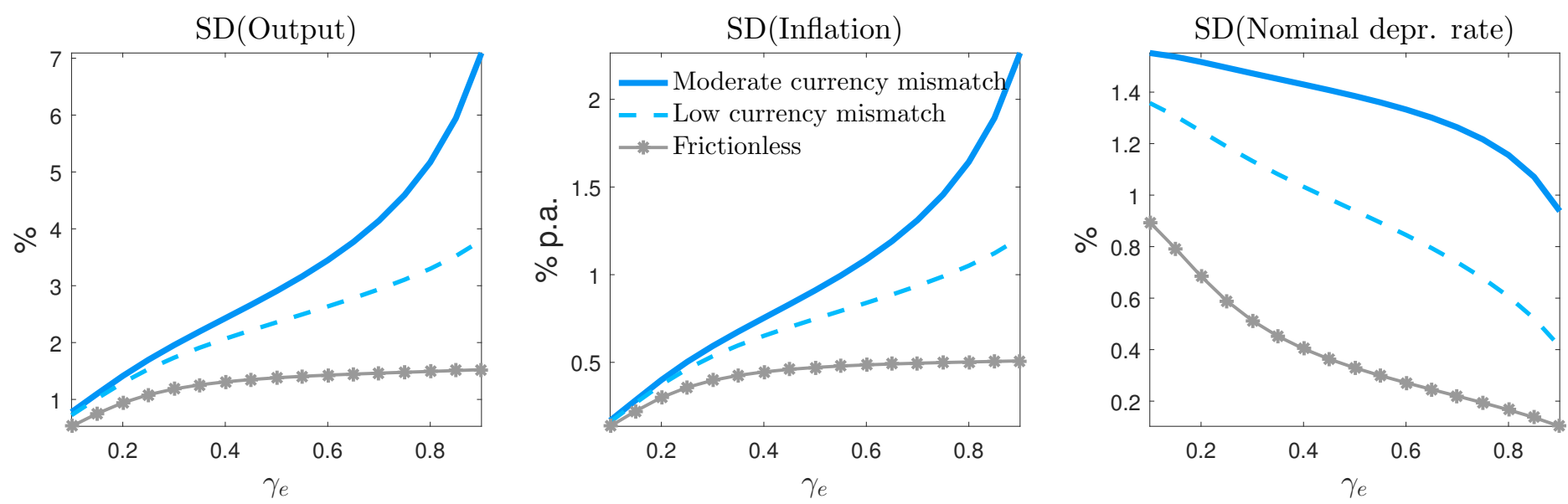

Note: The Figure shows the standard deviations of output, inflation, and the nominal depreciation rate for different values of $\gamma_{e}$ in the economies with low currency mismatch (light blue dashed line), with moderate currency mismatch (blue solid line), and without frictions (gray line with asterisks).

lower rows respectively). The green lines in Figure 8 display the outcomes conditional on a relatively small weight on the NER $\left(\gamma_{e}=0.05\right)$ and the blue lines shows them conditional on a relatively high weight on NER stabilization $\left(\gamma_{e}=0.40\right)$. The rule that gives a higher weight to NER is successful in moderating the depreciation in the economy with low currency mismatches: the home currency depreciates about 140 basis points on impact under the rule with $\gamma_{e}=0.05$, compared to just 60 basis points under the rule with $\gamma_{e}=0.40$. The smaller exchange rate movement, however, comes at the cost of a significantly larger output contraction, of about 70 basis points. This result accords with the findings by Gali and Monacelli (2005), who show that policy rules that entail lower output gap volatility (and thus higher welfare) also entail higher exchange rate volatility.

How does the degree of currency mismatch affect the consequences of following rule with a higher weight on the NER? Consider first the economy with a moderate degree of currency mismatch, shown in the middle row of Figure 8. The NER-targeting rule still helps moderate the movement in the nominal exchange rate, but the gain is now much smaller quantitatively: the NER depreciates about 200 basis points on impact under the high- $\gamma_{e}$ rule, compared to 240 basis points when $\gamma_{e}$ is small. Further, the output drop is now much larger - almost four times as large as under the low- $\gamma_{e}$ rule. Thus, cost in terms of output losses of stabilizing the NER is considerably higher than in the economy with low currency mismatch. This 
Figure 8: U.S. monetary tightening, different monetary regimes

\section{Low currency mismatch}
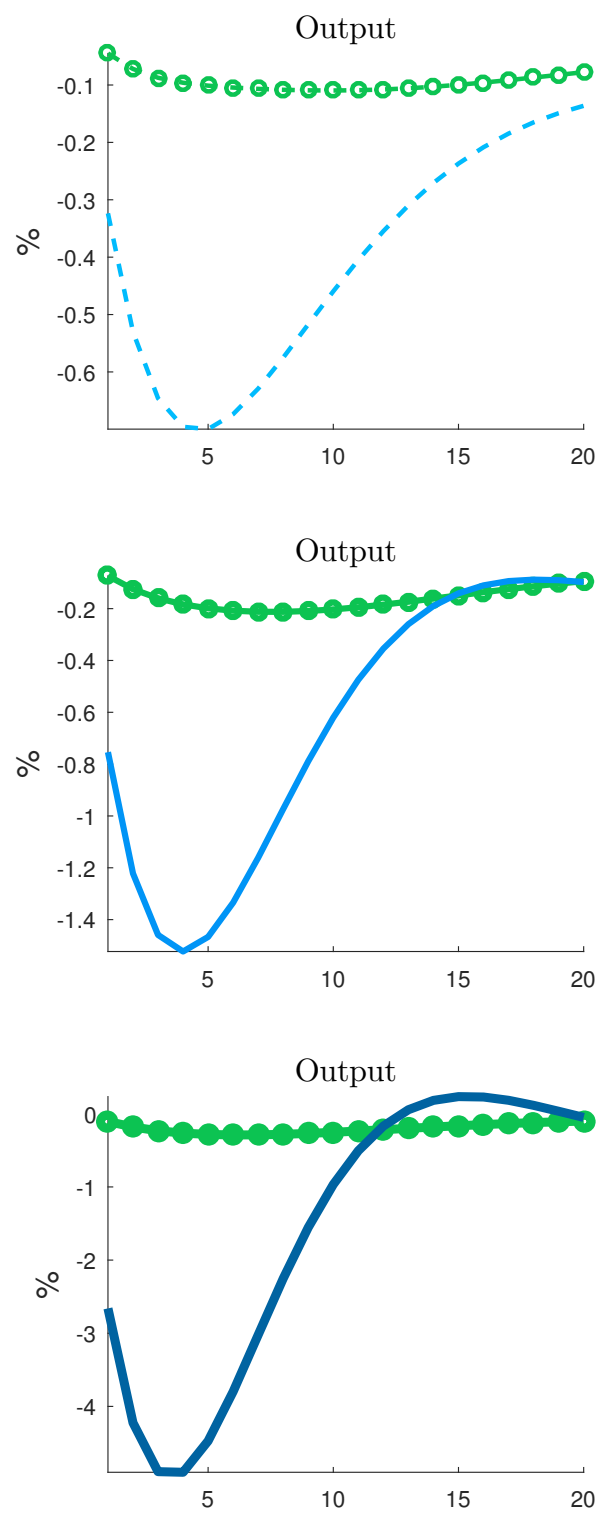
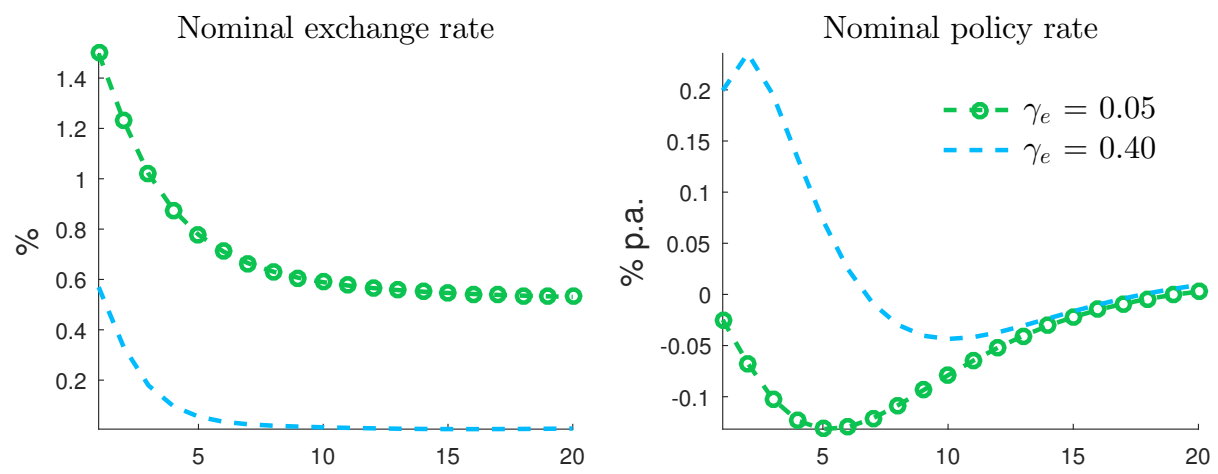

Moderate currency mismatch
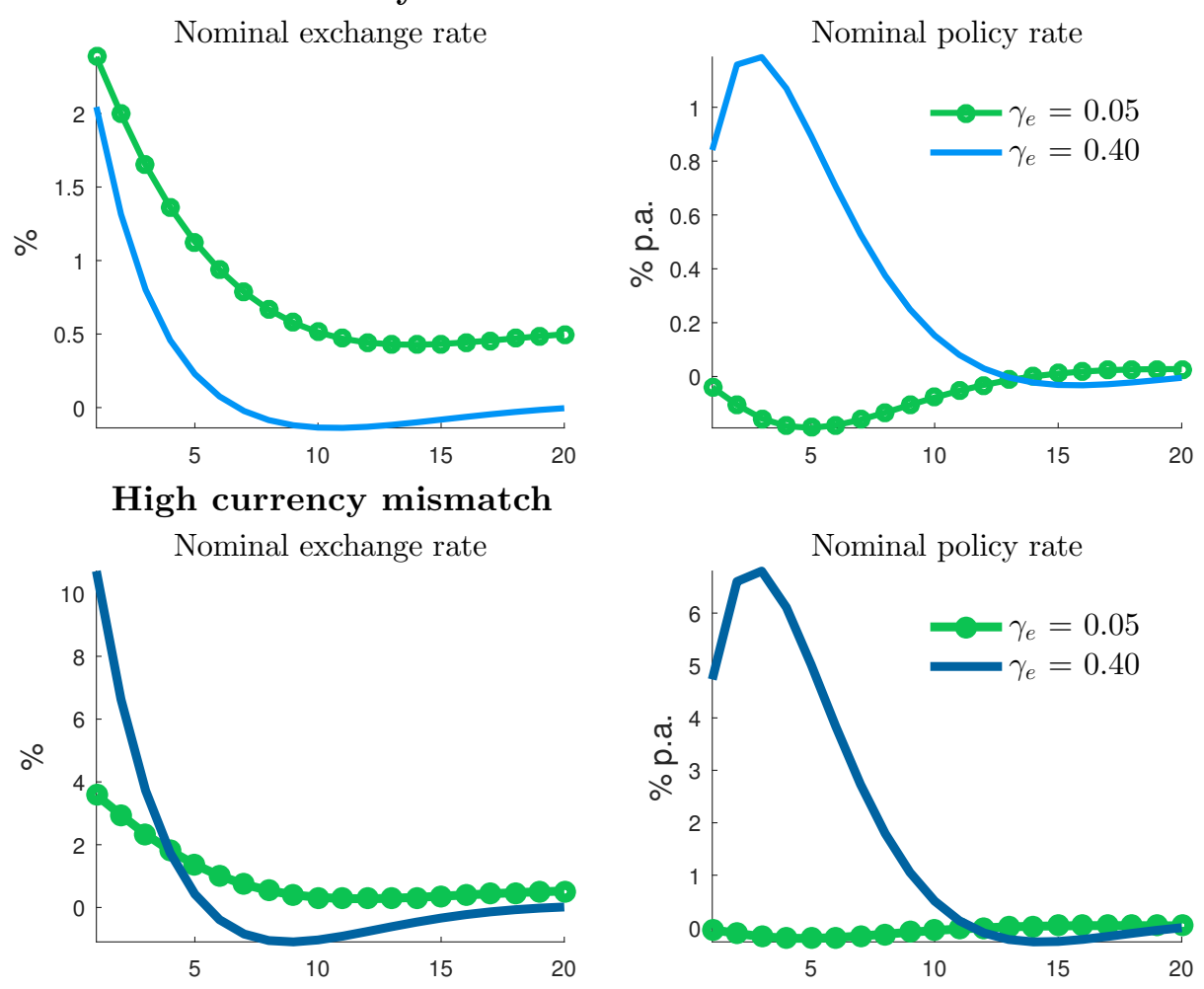

Note: The Figure shows the effects of U.S. monetary tightening under different policy regimes: $\gamma_{e}$ captures a regime characterized mostly by domestic inflation targeting, while $\gamma_{e}$ captures a regime with significant exchange-rate stabilization motives. The top, middle, and bottom rows refer to the economies with low, moderate, and high currency mismatch, respectively.

is a consequence of two forces: First, because a domestic monetary tightening raises the currency premium, the policy rate needs to raise by more, ceteris paribus, to achieve a given 
appreciation. Second, higher degree of currency mismatch implies a larger exchange-rate depreciation due to a U.S. rate hike of a given size.

These basic forces play out in a much more dramatic way in the economy with high degree of currency mismatch, shown in the bottom row. Because raising the domestic policy rate now induces a currency depreciation in the short run (due to an enormous upward movement in the currency premium), attempting to defend the currency turns out to be disastrous in this case. With high $\gamma_{e}$ the monetary authority raises policy rates sharply, inducing an enormous output decline; and it still does not succeed in halting the depreciation, with the currency falling by almost ten percent in the short run, more than twice as much as under the baseline rule with a smaller weight on the NER.

Taken together, the findings above cast doubt on the conventional argument that currency mismatch provides grounds for a rule that includes exchange rate: even when the degree of currency mismatch is low, the rule stabilizes the NER by less at the cost of a larger decline in output. In the more extreme case of high currency mismatch, the rule implies an enormous output drop, and actually fails at moderating the short-run depreciation.

\section{Empirics: Credit Spreads and Exchange Rates}

Standard open economy macroeconomic models with either complete or incomplete international financial markets, such as Gali and Monacelli (2005), assume UIP condition holds. This means that expected exchange rate depreciation in one country has to be equal to the difference between its short term interest rate on its deposits and the corresponding interest rate that a typical investor would earn if he invested in short term deposits in the other country; i.e, there are no ex ante excess returns from holding deposits in one country relative to another. ${ }^{16}$ However, the failure of the UIP condition in the data is a long-standing and well documented puzzle in international finance (see, for example, the seminal contribution of Fama (1984) and the excellent survey paper by Engel (2014)).

The UIP wedge or the currency premium in our model arises endogenously due to balance sheet constraints faced by the banks and it is strongly linked to domestic credit spreads in the home country. To provide evidence that there is empirical connection between the UIP spreads and credit spreads, we run the following regression using both the actual data and

\footnotetext{
${ }^{16}$ Note that open economy macroeconomic models with incomplete financial market models assume an ad-hoc foreign exchange risk premium solely for the purpose of rendering stationarity which does not play significant role in the determination of exchange rates.
} 
Table 2: Currency Premium and Credit Spreads

\begin{tabular}{lll} 
Explanatory Variables & Data & Model \\
\hline Interest diff., $\left(i_{t}-i_{t}^{*}\right)$ & $\begin{array}{l}1.16^{* * *} \\
(0.23)\end{array}$ & 0.00 \\
Credit Spreads, $C S_{t}$ & $\begin{array}{l}2.15^{* * *} \\
(0.80)\end{array}$ & {$[0.34-1.33]$} \\
& $0.31^{* * *}$ & - \\
Global Risk, VIX & $(0.01)$ & \\
& $Y e s$ & \\
Country Fixed Effect & $Y e s$ \\
Time Fixed Effect & Pooled OLS \\
\hline $\begin{array}{l}\text { Method } \\
R^{2}\end{array}$ & 0.60 \\
\# of Observations & 410 \\
\hline
\end{tabular}

Notes: Countries included in the pooled OLS regression are Korea, Brazil, Mexico, Chile, Indonesia, Colombia, Thailand and Turkey. This table presents estimates of a, $b$ and $\mathrm{c}$ from the regression $e_{t}-e_{t+1}+\left(i_{t}-i_{t}^{*}\right)=a+b\left(i_{t}-i_{t}^{*}\right)+c C S_{t}+d V I X_{t}+u_{t+1}$. The standard errors for the panel estimations are computed according to the Driscoll and Kraay (1998) method that is robust to heteroskedasticity, serial correlation and contemporaneous correlation across equations.

the model simulated data:

$$
\underbrace{e_{t}-e_{t+1}+\left(i_{t}-i_{t}^{*}\right)}_{\log \left(\mu_{t}^{*}\right)}=a+b\left(i_{t}-i_{t}^{*}\right)+c C S_{t}+d V I X_{t}+u_{t+1}
$$

where the dependent variable is the empirical counterpart of the logarithm of excess currency premium, $\mu^{*}$. The variable $i_{t}$ is the home one period nominal interest for deposits that pay off in period $t+1$ and $i_{t}^{*}$ is the corresponding US interest rates. We denote nominal exchange as $e_{t}$, the log of the foreign exchange rate, expressed as home currency price of the U.S. dollar (increase means a depreciation of home currency). The variable, $C S_{t}$, stands for corporate credit spreads and $V I X_{t}$ is included in the regression as a proxy for global risk which is shown to be important driver of global asset prices (see, for example, Rey (2015)). 
Table 2 presents our estimation results for the 1995-2017 period using quarterly data. As a reference, the same table also shows the results from the model simulated data. ${ }^{17}$ As shown in the second column of Table 2, the empirical regression predicts that there is very tight and significant relationship between the UIP wedge and the credit spreads, as in the model, even after controlling for several factors such as interest rate differential and a measure of global risk. ${ }^{18}$ These results are also broadly consistent with the empirical findings documented in Corte et al. (2015) and Hofmann et al. (2016).

\section{Conclusion}

We have developed a medium-scale quantitative New Keynesian model representing the U.S. economy and an emerging market economy. The latter is subject to financial frictions and dollar denominated debt in the balance sheets of banks, which gives rise to a selfreinforcing feedback loop between currency premium, exchange rate and financial conditions. We investigated the consequences of this mechanism for spillovers from U.S. monetary policy shocks and desirability of mitigating exchange rate depreciations using domestic monetary policy.

We showed that our model economy, which is reasonably calibrated to represent the U.S. economy and an emerging market economy, predicts that expenditure-switching and expenditure-reducing channels broadly cancel each other and U.S. monetary spillovers are larger for economies with larger dollar denominated liabilities (i.e. financial spillovers determine the overall size of spillovers).

Regarding the desirability of mitigating exchange rate fluctuations, our results call into question the common view. Our findings suggest that using monetary policy to stabilize the exchange rate is not necessarily more desirable with greater balance sheet mismatches, and may actually exacerbate short-run exchange rate volatility.

\footnotetext{
${ }^{17}$ The regression coefficient on model-simulated data depends on the degree of currency mismatch. Higher currency mismatch case has higher elasticity of the currency risk premium with respect to credit spreads, as given by the upper bound of the interval.

${ }^{18}$ The results do not change if we include the lagged dependent variable and lagged credit spreads in the regressions.
} 


\section{References}

Aghion, Philippe, Philippe Bacchetta, and Abhijit Banerjee, "Currency crises and monetary policy in an economy with credit constraints," European economic review, 2001, $45(7), 1121-1150.1$

_ , _, and _, "A corporate balance-sheet approach to currency crises," Journal of Economic theory, 2004, 119 (1), 6-30. 1

Aoki, Kosuke, Gianluca Benigno, and Nobuhiro Kiyotaki, "Monetary and financial policies in emerging markets," in "Economic Growth and Policy Conference" 2016. 1

Baskaya, Yusuf Soner, Julian di Giovanni, Sebnem Kalemli-Ozcan, and Mehmet Fatih Ulu, "International Spillovers and Local Credit Cycles," 2018. 1

Bocola, Luigi and Guido Lorenzoni, "Financial crises and lending of last resort in open economies," Technical Report, National Bureau of Economic Research 2017. 1

Boz, Emine, Gita Gopinath, and Mikkel Plagborg-Moller, "Global Trade and the Dollar," 2017 2017. The Economist -\&nbsp;New research suggests the dollar's level drives world trade. 3

Braggion, Fabio, Lawrence J. Christiano, and Jorge Roldos, "Optimal monetary policy in a [']sudden stop'," Journal of Monetary Economics, May 2009, 56 (4), 582-595. 1

Bruno, Valentina and Hyun Song Shin, "Capital flows and the risk-taking channel of monetary policy," Journal of Monetary Economics, 2015, 71 (C), 119-132. 1

Calvo, Guillermo A and Carmen M Reinhart, "Fear of floating," The Quarterly Journal of Economics, 2002, 117 (2), 379-408. 1

Carrillo, Julio A., Rocio Elizondo, Cid Alonso Rodriguez-Perez, and Jessica Roldan-Pena, "What Determines the Neutral Rate of Interest in an Emerging Economy?," 2017. 4.1

Casas, Camila, Federico J Dez, Gita Gopinath, and Pierre-Olivier Gourinchas, "Dominant Currency Paradigm," Working Paper 22943, National Bureau of Economic Research December 2016. 4.3.1 
Céspedes, Luis Felipe, Roberto Chang, and Andres Velasco, "Balance sheets and exchange rate policy," American Economic Review, 2004, 94 (4), 1183-1193. 1

Chui, Michael KF, Emese Kuruc, and Philip Turner, "A new dimension to currency mismatches in the emerging markets-non-financial companies," 2016. 4, 4.1

Corsetti, Giancarlo, Luca Dedola, and Sylvain Leduc, "Exchange Rate Misalignment, Capital Flows, and Optimal Monetary Policy Trade-offs," 2018. 1

Corte, Pasquale Della, Lucio Sarno, Maik Schmeling, and Christian Wagner, "Exchange Rates and Sovereign Risk," 2015. 5

Daniel, Christine A Mc and Edward J Balistreri, "A review of Armington trade substitution elasticities," Economie internationale, 2003, (2), 301-313. 10

Engel, Charles, "Chapter 8 - Exchange Rates and Interest Parity," in Gita Gopinath, Elhanan Helpman, and Kenneth Rogoff, eds., Handbook of International Economics, Vol. 4 of Handbook of International Economics, Elsevier, 2014, pp. 453 - 522. 5

_ , "Exchange Rates, Interest Rates, and the Risk Premium," American Economic Review, February 2016, 106 (2), 436-74. B

Erceg, Christopher, Christopher Gust, and David Lopez-Salido, The Transmission of Domestic Shocks in Open Economies, University of Chicago Press, June 1, 3, 4.1

Erceg, Christopher J., Dale W. Henderson, and Andrew T. Levin, "Optimal monetary policy with staggered wage and price contracts," Journal of Monetary Economics, 2000, $46(2), 281-313.3 .2,3.3$

Erceg, Christopher J, Luca Guerrieri, and Christopher Gust, "Expansionary fiscal shocks and the US trade deficit," International Finance, 2005, 8 (3), 363-397. 10, 4.1

_, _, and _ , "SIGMA: A New Open Economy Model for Policy Analysis," International Journal of Central Banking, 2006. 3.3, 4.1

Fama, Eugene F., "Forward and spot exchange rates," Journal of Monetary Economics, $1984,14(3), 319-338.1,5$

Gabaix, Xavier and Matteo Maggiori, "International liquidity and exchange rate dynamics," The Quarterly Journal of Economics, 2015, 130 (3), 1369-1420. 1 
Gali, Jordi and Tommaso Monacelli, "Monetary Policy and Exchange Rate Volatility in a Small Open Economy," Review of Economic Studies, 2005, 72 (3), 707-734. 1, 3, 4.4, $4.4,5$

_ and _, "Understanding the Gains from Wage Flexibility: The Exchange Rate Connection," American Economic Review, December 2016, 106 (12), 3829-68. 15

Gertler, Mark and Nobuhiro Kiyotaki, "Financial Intermediation and Credit Policy in Business Cycle Analysis," in Benjamin M. Friedman and Michael Woodford, eds., Handbook of Monetary Economics, Vol. 3, Elsevier, 2010, chapter 11, pp. 547-599. 1, 3

- and Peter Karadi, "A model of unconventional monetary policy," Journal of Monetary Economics, 2011, 58 (1), 17 - 34. 1, 3

_, Simon Gilchrist, and Fabio M Natalucci, "External constraints on monetary policy and the financial accelerator," Journal of Money, Credit and Banking, 2007, 39 (2-3), 295-330. 1

Goldberg, Linda S. and Cdric Tille, "Vehicle currency use in international trade," Journal of International Economics, December 2008, 76 (2), 177-192. 4.3.1

Goldstein, Morris and Philip Turner, Controlling currency mismatches in emerging markets, Columbia University Press, 2004. 4, 4.1

Gopinath, Gita, "The International Price System," Jackson Hole Symposium Proceedings, 2016. 3, 4.3.1

Gould, David M and Steven B Kamin, "The impact of monetary policy on exchange rates during financial crises," Financial crises in emerging markets, 2001, pp. 384-420. 1

Hausmann, Ricardo, Ugo Panizza, and Ernesto Stein, "Why do countries float the way they float?," Journal of development economics, 2001, 66 (2), 387-414. 1

Hnatkovska, Viktoria, Amartya Lahiri, and Carlos A. Vegh, "The Exchange Rate Response to Monetary Policy Innovations," American Economic Journal: Macroeconomics, April 2016, 8 (2), 137-81. 1

Hofmann, Boris, Ilhyock Shim, and Hyun Song Shin, "Sovereign yields and the risktaking channel of currency appreciation," BIS Working Papers 538, Bank for International Settlements January 2016. 5 
Holston, Kathryn, Thomas Laubach, and John C Williams, "Measuring the natural rate of interest: International trends and determinants," Journal of International Economics, 2017, 108, S59-S75. 4.1

Hooper, Peter, Karen Johnson, and Jaime R Marquez, "Trade elasticities for the G-7 countries," 2000. 10, 4.1

Ilzetzki, Ethan, Carmen M. Reinhart, and Kenneth S. Rogoff, "Exchange Arrangements Entering the 21st Century: Which Anchor Will Hold?," Working Paper 23134, National Bureau of Economic Research February 2017. B

Justiniano, Alejandro, Giorgio E Primiceri, and Andrea Tambalotti, "Investment shocks and business cycles," Journal of Monetary Economics, 2010, 57 (2), 132-145. 3.7, 4.1

Kalemli-Ozcan, Sebnem, Herman Kamil, and Carolina Villegas-Sanchez, "What Hinders Investment in the Aftermath of Financial Crises: Insolvent Firms or Illiquid Banks?," The Review of Economics and Statistics, 2016, 98 (4), 756-769. 1

Krugman, Paul, "Balance sheets, the transfer problem, and financial crises," International finance and financial crises, 1999, 6 (4), 459-472. 1

Magud, Mr Nicolas E and Evridiki Tsounta, To cut or not to cut? That is the (central banks) question in search of the neutral interest rate in Latin America number 12-243, International Monetary Fund, 2012. 11

Niepmann, Friederike and Tim Schmidt-Eisenlohr, "Foreign Currency Loans and Credit Risk: Evidence from U.S. Banks," 2017. 1

Reifschneider, David, "Gauging the Ability of the FOMC to Respond to Future Recessions," 2016. 4.1

Reinhart, Carmen M, "Mirage of floating exchange rates," American Economic Review, 2000, $90(2), 65-70.4 .4$

Rey, Helene, "Dilemma not Trilemma: The Global Financial Cycle and Monetary Policy Independence," Working Paper 21162, National Bureau of Economic Research May 2015. 5 


\section{A Details on simple model}

\section{A.1 Aggregate resource constraint}

Here we derive the balance of payments equations (9), (10) by aggregating domestic budget constraints. The term $\pi_{t}$ in $(7)$ is

$$
\begin{aligned}
\pi_{t} & =\int\left\{\left(r_{k}+q_{t}\right) S_{i t-1}-R D_{i t-1}-R^{*} \mathcal{Q}_{t} D_{i t-1}^{*}-\xi_{i t}\right\} d i \\
& =\left(r_{k}+q_{t}\right) \bar{K}-R D_{t-1}-R^{*} \mathcal{Q}_{t} D_{t-1}^{*}-\int \xi_{i t} d i \\
& =r_{k} \bar{K}-R D_{t-1}-R^{*} \mathcal{Q}_{t} D_{t-1}^{*}+D_{t}+\mathcal{Q}_{t} D_{t}^{*}
\end{aligned}
$$

where the second equality uses the bank's budget constraint (1). Substituting the above equation into households' budget constraint at equality yields

$$
C_{D t}+\mathcal{Q}_{t} M_{C t}=W_{t} \bar{L}+r_{k} \bar{K}-R^{*} \mathcal{Q}_{t} D_{t-1}^{*}+\mathcal{Q}_{t} D_{t}^{*}
$$

Using the market-clearing condition for the home good $C_{D t}+M_{C t}^{*}=Y_{t}$ and the zero-profit condition for home firms $Y_{t}=W_{t} \bar{L}+r_{k} \bar{K}$ in the equation above yields (9) and (10).

\section{A.2 Steady state}

The deterministic steady state can be solved in closed form:

$$
\begin{aligned}
\mu & =\left(1-\frac{\beta}{\beta^{*}}\right) \frac{1}{\gamma} \\
x & =\left(\frac{\xi}{\theta-\mu}-1\right) \frac{1}{\gamma} \\
q & =\frac{\frac{\beta}{1+\mu}}{1-\frac{\beta}{1+\mu}} r_{k} \\
\mathcal{Q} & =\frac{\left(\beta^{*-1}-1\right) x q \bar{K}+\chi_{m}}{\chi_{x}}
\end{aligned}
$$

From (A.1), $\beta<\beta^{*}$ ensures $\mu>0$. A binding incentive constraint requires

$$
\theta-\mu=\theta-\left(1-\frac{\beta}{\beta^{*}}\right) \frac{1}{\gamma}>0
$$


i.e. $\theta$ must be large enough, given $\beta, \beta^{*}$, and $\gamma$. For the foreign borrowing ratio $x$ to be positive in steady state, the parameters need to satisfy

$$
\xi>\theta-\mu=\theta-\left(1-\frac{\beta}{\beta^{*}}\right) \frac{1}{\gamma}
$$

i.e. $\xi$ (the steady-state net worth transfer, as a fraction of the capital stock) must be large enough. In addition, for $x$ to be smaller than 1 the condition

$$
\xi<(1+\gamma)(\theta-\mu)=(1+\gamma)\left(\theta-\left(1-\frac{\beta}{\beta^{*}}\right) \frac{1}{\gamma}\right)
$$

must be satisfied, i.e. $\xi$ cannot be too large.

\section{A.3 Loglinearized equilibrium conditions}

Let $\widehat{y}_{t} \equiv \log \left(\frac{y_{t}}{y}\right)$ and $\widetilde{y}_{t} \equiv y_{t}-y$ for any variable $y_{t}$, where variables without time subscripts refer to the non-stochastic steady state. A first-order approximation to (11)-(15) yields the following system of difference equations:

$$
\begin{aligned}
\widetilde{\mu}_{t} & =-\frac{\theta-\mu}{\xi} \widetilde{\xi}_{t}+\frac{\gamma x \xi}{(1+\gamma x)^{2}} \widehat{x}_{t} \\
\widehat{x}_{t} & =\widehat{\mathcal{Q}}_{t}+\widehat{D}_{t}^{*}-\widehat{q}_{t} \\
\widehat{\mathcal{Q}}_{t} & =\gamma \frac{\beta^{*}}{\beta} \widetilde{\mu}_{t}+\mathbb{E}_{t}\left\{\widehat{\mathcal{Q}}_{t+1}\right\} \\
\widehat{q}_{t} & =-\frac{1}{1+\mu} \widetilde{\mu}_{t}+\frac{\beta}{1+\mu} \mathbb{E}_{t}\left\{\widehat{q}_{t+1}\right\} \\
\widehat{D}_{t}^{*} & =-\varepsilon \widehat{\mathcal{Q}}_{t}+\frac{1}{\beta^{*}} \widehat{D}_{t-1}^{*}
\end{aligned}
$$

where

$$
\varepsilon \equiv \frac{\chi_{m}\left(\frac{1}{\beta^{*}}-1\right)}{\chi_{x} \mathcal{Q}-\chi_{m}}
$$

Next let $\beta \rightarrow \beta^{*}$ from below (which implies $\mu \rightarrow 0$ from above, as can be seen from (A.1)), and assume $\chi_{x}=\chi_{m} \equiv \chi$ (symmetric preferences over the foreign good). In addition, normalize $\bar{K}$ such that $\varepsilon=\frac{1}{\beta^{*}}-1$, which from (A.10) entails ensuring that $\mathcal{Q}=2$, in turn 
requiring from (A.3),(A.4) that $\bar{K}$ be set so as to satisfy

$$
\alpha \bar{K}^{\alpha}=\frac{\chi}{x}
$$

with $x$ given by (A.2), where we have made use of the expression for the capital return $r_{k}=\alpha(\bar{K} / \bar{L})^{\alpha-1}$ and the normalization $\bar{L}=1$. Note from (10) that $\mathcal{Q}=2$ makes the elasticity of net exports to $\mathcal{Q}_{t}$ equal to unity. Under these assumptions, equations (A.5), (A.7)-(A.9) simplify to

$$
\begin{aligned}
\widetilde{\mu}_{t} & =-\frac{\theta}{\xi} \widetilde{\xi}_{t}+\frac{\theta}{\xi}(\xi-\theta) \widehat{x}_{t} \\
\widehat{\mathcal{Q}}_{t} & =\gamma \widetilde{\mu}_{t}+\mathbb{E}_{t}\left\{\widehat{\mathcal{Q}}_{t+1}\right\} \\
\widehat{q}_{t} & =-\widetilde{\mu}_{t}+\beta \mathbb{E}_{t}\left\{\widehat{q}_{t+1}\right\} \\
\widehat{D}_{t}^{*} & =-r^{*} \widehat{\mathcal{Q}}_{t}+\left(1+r^{*}\right) \widehat{D}_{t-1}^{*}
\end{aligned}
$$

where $r^{*} \equiv \frac{1}{\beta^{*}}-1$ denotes the net foreign interest rate, and where we have made use of (A.2) in going from (A.5) to (A.11).

\section{B Data}

This section review the data sources used in analysis of section 5. More specifically, below is information on the exchange rates, interest rates and corporate spread data used in the empirical analysis. Countries are included in the data set when the currencies have a flexible currency regime (or, fluctuations in exchange rate is contained in a band that is wider than plus and minus 2 percent according to the definition given in Ilzetzki et al. (2017). The start data of the data is different for each country. Data ends in November 2017. For Fama regressions, data sets are constructed using the last trading day of the month (quarter) for if the regression is monthly (quarterly).

\section{Exchange Rates}

Exchange rates are end of day spot rates from Bloomberg and are measured in units of foreign country / USD. 


\section{Interest Rates}

Interest rates are 1M deposit rates and follow conventions from Exchange Rates, Interest Rates, and the Risk Premium paper by Engel (2016). For Turkey, Brazil, Indonesia, Singapore, interest rates are the average of offer and bid rates of 1Month Deposit rates. For Chile, Colombia, Thailand, Korea and Mexico, Uruguay and the Philippines data are 1 Month deposit rates from Haver. We also used 3M deposit rates in the regressions and the results do stay the same.

\section{Corporate Spread Data}

We use the BBB corporate spread data for Brazil, Korea, Mexico, EMBI data for Chile, Indonesia, Thailand, Uruguay, and EMBI+ for Colombia, Philippines, South Africa, Turkey. These data are retrieved from Bloomberg. 